\title{
Assisi Szent Ferenc és Melek al-Kámil szultán találkozója 1219-ben Egy 800 évvel ezelőtti esemény történelmi háttere és a „vallásközi dialógus” lehetősége az V. keresztes hadjárat éveiben
}

\author{
Csik Tamás \\ csiktamas@gmail.com
}

Csik T. (2019): Assisi Szent Ferenc és Melek al-Kámil szultán találkozója 1219-ben. Egy 800 évvel ezelötti esemény történelmi háttere és a „vallásközi dialógus” lehetösége az V. keresztes hadjárat éveiben. The Meeting between Saint Francis of Assisi and Sultan Melek al-Kamil in 1219. The Historical Background of an Event Happened 800 Years ago and the Possibility of the Interreligious Dialogue in the Years of the Fifth Crusade. Acta Pintériana, 5: 143-165.

\begin{abstract}
This study presents the historical background of the meeting between Saint Francis of Assisi and the Egyptian Sultan, al-Kámil in 1219. In one respect, due to the lack of reliable historical sources, as well as the particular nature of the historical interpretation, we can only write about one aspect of the meeting held during the bloody events of the Fifth Crusade. On the basis of the specialized literature and the sources referring to the meeting indirectly, it has been verifiable that the real aftermath of the meeting appeared as an exemplary model for the initiative of an interreligious dialogue. As the summary of the study it is important to emphasize that the precondition of a successful dialogue between religions was the participants' openness towards each other and the assessment of the actual relationship of power as well as the political circumstances on a realistic way.
\end{abstract}

\section{Bevezetés}

A ferences rend 2019-ben ünnepli Assisi Szent Ferenc (1181/1182-1226) és Melek al-Kámil (11771238) egyiptomi szultán találkozójának 800. évfordulóját.

Jelen tanulmány célja kettős: elöször, hogy a történész tárgyilagosságával magyar nyelven első ízben adjon pontos képet a történetileg igazolt - mind keresztény, mind muszlim források által alátámasztott - találkozóról; másodszor pedig, hogy az alapvető szakirodalom magyar nyelvü feldolgozásával további kutatások és eszmecserék megbízható bázisául szolgáljon.

Sajnálatos módon napjaink aktuálpolitikai eseményei elkerülhetetlenül rányomják torzított képüket a jubileumra. Egy történetileg hiteles megközelítés azonban nem nélkülözheti a korabeli kontextusba helyezett objektív bemutatást, amely tovább vezet a nyitva maradó, nem feltétlen a történelemtudomány területéhez tartozó kérdések (pl. a résztvevők személyiségvonásainak, indítékainak, egyéni céljainak) kutatása felé. E tanulmány nem foglal állást a jelenleg felkapott, de sokszor csak felületesen és közhelyesen tárgyalt vallásközi dialógust érintő, ill. emberjogi-politikai kérdésekben. Ha nem törekednénk erre a történeti hüségre, akkor ez a múltbéli találkozó pontosan a konkrét körvonalait és karizmatikus egyediségét, vagyis a hitelességét veszítené el. 


\section{Az V. keresztes hadjárat első szakasza és a ferences rend korai évei}

\section{Az V. keresztes hadjárat történeti előzményei}

A 12. század keresztes háborúi nyilvánvalóvá tették, hogy egy központi irányítással rendelkező, „egységes” muszlim állam igen hatékonyan tud fellépni egy vezetésében, így céljaiban is differenciált keresztes sereg, jobban mondva seregtestek ellen. Az egymással vetélkedő, hadmozdulataikat csak ritkán koordináló uralkodók hadjáratai (1147-1149 és 1189-1190) nemhogy megerősítették volna az első keresztes hadjárat nyomán létrehozott szentföldi keresztény államokat, hanem a muszlim seregek által fenyegetett, még meglévő területek megoltalmazását sem tudták biztosítani. A 12. századot az Antiochiai Fejedelemség és a Tripoliszi Grófság többé-kevésbé sértetlenül vészelte át, de az Edesszai Grófság és a Jeruzsálemi Királyság nagy része magával Jeruzsálemmel együtt elveszett. A Jeruzsálemi Királyság csupán egy szélesebb part menti sávot mondhatott magáénak Akkon központtal. A keresztes államok esetében központi irányításról, egységes fellépésről csak korlátozottan beszélhetünk, inkább az európai államokra jellemző hübéri függésben lévő elitek torzsalkodása követhető nyomon a Szentföldön is (1. térkép).

A 13. században változás figyelhető meg a keresztes eszmét és mozgalmat illetően, amely összefüggésben áll az akkori Európa gazdasági, kulturális, politikai expanziójával. Egyrészt térben kiszélesedik és nem korlátozódik csupán a Szentföldre, másrészt jelentése és célkitüzései módosulnak az eredeti célhoz képest. A Szentföld és a szentföldi zarándokok védelme, valamint Jeruzsálem visszaszerzése továbbra is mindenki által elfogadott és támogatott hivatkozási alap marad, de egyre inkább nyilvánvalóvá válik, hogy a kezdeti lelkesedés, fegyelem, buzgóság, hit és erkölcs megfogyatkozik. Helyettük új, nem feltétlenül a legnemesebb szándékok által vezérelt tervek jelentek meg a hadjáratok célját illetően. A gazdasági, politikai, stratégiai, kereskedelmi célok mindjobban háttérbe szorították az eredeti keresztes eszmét.

A hagyományosan 1217 és 1221 közé datált ${ }^{1}$ V. keresztes hadjáratot két, Jeruzsálem visszahódítására irányuló „hadjárat” előzte meg az új században. Az első, a IV. keresztes hadjárat néven elhíresült hódító hadművelet (1202-1204) I. Amalrik jeruzsálemi király (1162-74), valamint Oroszlánszívü Richárd angol király (1157-1199) terveit felújítva az egyiptomi muszlim uralmat megdöntve kívánta szavatolni a szíriai keresztény államok biztonságát és az elveszett területek visszahódítását. A célját nemhogy nem érte el, de hadjárat vezetői és Velence hírhedt politikai mesterkedései nyomán először fordult elö, hogy keresztesek keresztény államokat támadtak meg. A keresztes hadjárat látszatára kínosan ügyelve először a dalmáciai Zára városát hódították el a Magyar Királyságtól; majd arra hivatkozva, hogy a szentföldi államokat és geopolitikai helyzetüket hathatósabban segíthessék megdöntötték a Bizánci Császárságot. Helyére új, latin császárságot állítottak fel, de az új geopolitikai helyzet a valóságban csak nehezítette a szentföldiek helyzetét. Nyugat-Európai és szíriai nemeseket és lovagokat hívtak meg megtelepedés céljából az új császárság területére, amely sokkal inkább vonzóbb volt, mint a komoly nehézségekkel küzdő szentföldi területek. Így egyrészt már meglévő erőforrásokat vontak el a Jeruzsálemi Királyságtól, másrészt potenciális emberi és anyagi utánpótlást akadályoztak meg (vö. RUNCIMAN 2002, pp. 541; 721-739).

A második ,hadjáratot” a 13. század elején a „gyermekek hadjárata” néven ismeri a történelem. A Francia Királyság és a Német-Római Császárság területén közel 10.000 szegény sorsú fiatal döntött

\footnotetext{
${ }^{1}$ A keresztes hadjáratok történetét feldolgozó Bozsóky Pál Gerő ferences egyháztörténész 1217 és 1219 közé datálta az eseményt. A széles forrásbázison alapuló és az egyháztörténeti kulcskérdésekre koncentráló összefoglaló azonban nem vette figyelembe, hogy a hadjárat csak 1221-ben ért véget a keresztesek és az egyiptomi szultán közötti fegyverszünettel (vö. BOzsóKY 1995, p. 102). A hasonló témában részletesebb monográfiát író Steven Runciman már pontosan jelezte a fegyvernyugvás megkötésének időpontját is kronologikus felépítésủ munkájában (vö. RUNCIMAN pp. 765-766).
} 
úgy 1212-ben, hogy kezükbe veszik a kezdeményezést és ők fogják fegyvertelenül, békés eszközökkel felszabadítani a Szentföldet és az 1187-ben muszlimok által elfoglalt Jeruzsálemet. ${ }^{2}$ A fanatizmusba hajló vallási felbuzdulásból induló „,hadjárat” tragédiába torkollott.

A fentebb említett két „hadjárat” nem jutott el a Szentföldre, tehát a Szaláh ad-Dín Júszuf (röviden és a továbbiakban: Szaladin) szultán 1187-es muszlim hódításai következtében beállott status quo, így a keresztes államok helyzete sem változott; további muszlim terjeszkedés fenyegetett, illetve a Szent Város visszafoglalásának ügye továbbra is aktuális maradt. Hogy a Szentföldről érkező rossz hírek nyomán mikor valósulhatott meg egy újabb keresztes hadjárat, az természetesen a felbuzduláson túl, nagyban függött a korabeli Európa hatalmi viszonyaitól és attól is, hogy akad-e alkalmas vezető, aki képes koordinálni a hadmüveleteket.

A 13. század elején a keresztes hadjárat és keresztes gondolat megélénkülése nemcsak Észak-Kelet Európában, a későbbi porosz területeken, hanem az Ibériai-félszigeten is nyomon követhető. A muszlimok által évszázadokkal korábban elfoglalt térségek visszahódítása, a reconquista komoly sikereket tudhatott magáénak. 1212. júliusi Las Navas de Tolosa melletti keresztény győzelemmel végződő hadjáratot a pápaság komoly keresztes mozgósítással támogatta. A közös fellépés megpecsételte a muszlim Almohádok ibériai-félszigeti hatalmát. Az itt bekövetkező keresztes győzelmek ugyancsak egy új, a Szentföldre indítandó hadjárat megszervezésének irányába hatottak (lásd BOZSÓKY 1995, pp. 139-142; RUNCIMAN 2002, pp. 741-749).

\section{A ferences rend első évei}

A 13. században megfigyelhető egyfajta felfokozott miszticizmus, amely nyomon követhető a kor vallási megújulásra törekvő mozgalmaiban. Meg kell említeni, hogy ez a megújulásra való törekvés nem csupán a keresztény vallást jellemzi ekkor, hiszen a szúfizmus elötérbe kerülése figyelhető meg a muszlim vallásban is. A keresztény indíttatású megújulási mozgalmak közül néhány, mint a ferences, domonkos, karmelita és szervita mozgalmak a szerzetesség megújulásához vezettek és a Katolikus Egyház lelki-szellemi megújulását is eredményezték. Mások, az előzőekhez képest rövidebb történelmi életủ rendek, mint például a humiliátus és begina mozgalmak, ill. betegápoló jellegü jámbor vallásos életformát folytató közösségek, szintén a Katolikus Egyház keretei között folytatták életüket és tevékenységüket. Ismét mások, albigensek, katharok, bogumilok, valdensek radikalizálódó mozgalmai mind a keresztény tanítás és hit, mind a fennálló társadalmi-politikai rend ellen lázadtak és a konfliktusok fegyveres összetüzésekhez, regionális háborúkhoz vezettek.

Pont ez a vallásilag felfokozott légkörü időszak, a 13. század első évtizede volt a legnagyobb befolyással az Assisiből származó Francesco di Pietro Bernardone-ra, a későbbi Szent Ferencre, és az általa alapított szerzetesrend sorsára. A dél-franciaországi albigens eretnekmozgalmak évei (lásd BOZSÓKY 1995, pp. 146-153), illetve a velük szembeni határozott egyházi fellépés a 13. század első évtizedének végén már csak azért is jelentett kritikus periódust Szent Ferenc és első társai számára, mivel az első rendi regula csak az évtized végén, 1209-ben kapta meg III. Ince pápa szóbeli jóváhagyását. A Jézus Krisztus szorosabb követésére irányuló, az evangéliumi szegénységben folytatott apostoli életforma követését célul kitüző karizmatikus vezető és csoportja könnyen kerülhetett volna akár az eretnekség gyanújába is, hiszen az első néhány évben megélt életformájuk külső jegyei hasonlíthattak az eretnekek életformájához. Szent Ferenc, megtérése után, 1207-ben egy

\footnotetext{
2 A hagyományosan a „gyermekek keresztes hadjárataként” említett 1212-es esemény történelmi hátterének feltárása során Bozsóky Pál Gerő utalt rá, hogy egyrészt csak a rajnai térségböl indulók érhették el bizonyíthatóan a Földközi-tenger térségét, ahol Brindisi püspöke határozottan megtiltotta számukra a hajóra szállást; másrészt inkább fiatal felnőttekről lehetett szó, (utalnunk kell itt a latin puer szó jelentéstartalmára, amely gyakran ,szolgát” is jelent) akiknek útra kelésében szerepet játszhatott egy termelési válság is, amelynek következtében a mezőgazdaságban dolgozók tömegei csak nehezen jutottak munkához (lásd BOZSÓKY 1995, pp. 168-175).
} 
szimbolikus cselekedettel adja vissza atyjának javait és ugyanezzel a cselekedettel kéri maga számára az Egyház oltalmát (1Cel 14-15), vagyis a Szent Ferenc által elindított közösség kezdettől fogva a Katolikus Egyház keretei között akart élni és müködni. A szegénységben élö, Isten szeretetét és az evangélium örömét hirdető Szent Ferenchez később társak is szegődnek, akikkel testvéri közösséget alkova 1209-ben azért ment Rómába, hogy a pápa áldását kérje az általuk megélt evangéliumi életformára.

Mivel a tanulmány kitüzött céljai között nem szerepel az 1209-es, úgynevezett Protoregula pápai jóváhagyása körülményeinek vizsgálata, így ezúttal nem térhetünk ki arra sem, hogy végül miként került erre sor. Annyit azonban mindenképpen fontos megjegyezni, hogy Róma már ekkor is láthatott lehetőséget a rend térítői feladatokkal való ellátásában, amennyiben sikerül müködését beilleszteni az egyházi keretek közé. Ebből a szempontból szintén nem mellékes, hogy míg 1211-ben, illetve 121314-ben Ferencet még nem az egyházi vezetés akadályozta meg abban, hogy az előbbi alkalommal a Szentföldre, majd később a marokkói szultánhoz eljusson; addig 1217-ben már a későbbi IX. Gergely pápa, Hugoliono de Conti di Segni bíboros gátolta meg, hogy francia területre menjen téríteni, mivel a római udvar feltehetően tartott a gyorsan népszerüvé váló fiatal rend tagjainak fegyelmezetlenségétől (vö. HOEBERICHTS 1997, p. 30).

Természetesen a rendtörténet korai szakaszáról írva, a ferences forrásokon kívül, sokszor csak feltételezésekre hagyatkozhatunk, így nem tudhatjuk pontosan azt sem, hogy Ferenc mikor gondolhatott elöször arra, hogy nyíltan jelzi támogatását az 1215-ben összehívott Lateráni Zsinat céljaival kapcsolatban. A rend 1217-es „,pünkösdi káptalanja” azonban döntést hozott a fentiekröl, majd két évvel később Szíria provincia létrehozásáról is (vö. MOSES 2009, pp. 60, 98-99). Ezzel a ferencesek nyíltan felvállalták a térítő tevékenységet a hadjáratban, amelynek katonái ekkor már vagy a Szentföldön voltak, vagy éppen a helyszínre tartottak. Mindez egyben azt is jelentette, hogy az új szerzetesrend kinyilvánította hajlandóságát az egyházi célok támogatására, és Rómának sem kellett már annyira gyanakvóan tekintenie rájuk, mint korábban. Az persze továbbra is kérdés volt, hogy a békét hirdető rendalapító és társai mennyire végzik majd tevékenységüket az egyházi elvárások szerint a keresztes hadjárat véres eseményei közepette.

\section{Az V. keresztes hadjárat kezdete; A Nílus-völgyének új ura, al-Kámil szultán (1217-1219)}

Az új, Szentföld muszlim uralom alól való felmentését kitüző keresztes hadjárat megszervezésével 1215-ig kellett várni. III. Ince pápa okulva az addigi keresztes hadjáratok eredményeiből, sikereiből, illetve eredménytelenségeiből és sikertelenségeiből új alapokra helyezte a hadjárat szervezését. Nem csupán az anyagi erőforrásokat, toborzásokat, hanem Európán belüli politikai ellentéteket is el kellett simítani négy évre szóló általános békét hirdetve. A hadjárat vezetésére megnyerte Hohenstauf II. Frigyes német királyt, a későbbi császárt, valamint János angol, és II. András magyar királyokat is. A hadjárat meghirdetésére az egyház és a hit megreformálására összehívott IV. Lateráni Zsinat tekintélyét használta fel. Az új hadjárat kezdő napjaként 1217 június elsejét jelölték meg. Az újabb fegyveres küzdelem meghirdetésének pillanatát részben a kényszer szülte, hiszen egyrészt lassan lejárt a mai Egyiptomot, Szíriát, az Arab-félsziget nyugati felét és a Szentföld jelentős részét birtokló Ajjúbida Birodalom akkori uralkodójával Szajf ad-Dín szultánnal (röviden és a továbbiakban: al-Ádil) 1212-ben kötött fegyverszünet öt éves időtartama, másrészt I. (Brienne-i) János - névleg Jeruzsálem királya - már ennek megkötésekor is sürgette az új hadjáratot.

A ferences káptalan döntése aligha lehetett volna aktuálisabb 1217-ben, hiszen az elöző évben megválasztott új pápa, III. Honorius irányítása alatt ekkor már nemcsak javában folyt a keresztes hadjárat szervezése, hanem a katonai erő egy jelentősebb része útnak indult a Szentföldre. Úgy tủnt azonban, mintha a sereg nem találna valódi hadicélt magának, és a kisebb-nagyobb muszlim erődítmények megtámadása után kifulladni látszott a szervezési problémákkal is küszködő hadjárat 
(vö. BOZSÓKY 1995, p. 100; RUNCIMAN 2002, pp. 750-752). Ez az időszak 1218 tavaszán ért véget, mikor az V. keresztes hadjárat vezetői egy kivitelezhetőnek tűnő célt fogalmaztak meg. Az elképzelés szerint, amennyiben a keresztes seregnek sikerül átkelnie Egyiptom földjére, és elfoglalná a Nílusdelta központjában található Damietta városát (2. térkép), akkor azzal egyrészt meggátolnák, hogy Jeruzsálem ostrom alá vétele esetén al-Ádil szultán tengeri úton küldjön erősítést a Szentföldre, másrészt egy kereskedelmi szempontból is fontos térség kerülne keresztény kézre. ${ }^{3}$ Ez utóbbi szempont különösen Velence számára lehetett fontos, amelynek kereskedői egy 1208-ban kötött szerződés révén egyébként is komoly nyereségre tettek szert egyiptomi üzleti érdekeltségeik nyomán. Ugyanakkor az európai államok és Egyiptom közötti virágzó kereskedelmi kapcsolatokat illetően érdemes megjegyezni azt is, hogy 1215-ben mintegy 3000, a kontinensről származó kereskedő élt a Nílus mentén (vö. RUNCIMAN 2002, pp. 752-754).

Éppen az utóbbi szempont, a keresztény világgal fenntartott, viszonylag békésnek tünő kapcsolat, és a fentebb már említett szerződések miatt történhetett az, hogy az idős al-Ádil szultán nem érzékelte a veszélyt, és nem tudott felkészülni a keresztes haddal szemben, amely 1218 májusában partra szállt a Nílus deltájában. Ezen túlmenően a saját birodalmán vagy családján belüli, gyakran harci cselekményeket is eredményező hatalmi vetélkedések is elvonták a szultán figyelmét a tenger felöl készülődő veszélyről (vö. RUNCIMAN 2002, pp. 753-754). Így amikor 1218. augusztus 24-én a keresztes had megkezdte Damietta ostromát, és pár nappal később, augusztus 31-én Damaszkuszban meghalt al-Ádil; már egyértelmü volt, hogy az Egyiptom feletti uralmat megöröklö fiának, alKámilnak kell majd megbirkóznia a háborús viszonyok jelentette kihívással, miközben fivérére, alMuazzamra marad Szíria irányítása, harmadik testvérük, al-Asraf, pedig a mezopotámiai részekért volt felelős (vö. RUNCIMAN 2002, p. 755). ${ }^{4}$

Egyiptom új uralkodójáról elmondható, hogy egészen a 13. század elején indított keresztes hadjáratig más muszlim birodalmakhoz képest viszonylag toleránsan viszonyult az itt élő keresztényekhez. Mindez következhetett a nyugati világgal ápolt virágzó kereskedelmi kapcsolatokból, neveltetéséből, a korabeli tudományok és filozófia iránti érdeklődéséből, illetve az előbbiekhez kapcsolódó humánusabb emberképből is. Ennek megfelelően al-Kámil uralkodóként szintén érdekelt volt a keresztény világgal való viszonylagos jó kapcsolatok fenntartásában. A szultán tudatos politikáját és hatalmi érdekeit szinte lehetetlen szétválasztani a toleránsabb filozófiai hagyományokhoz való, vagy éppen az iszlám misztikus, kifejezetten békés irányzatához, a szúfizmushoz való személyes vonzódásától, valamint az ebből következő, az utókor által al-Kámilnak tulajdonított személyiségjegyektől. Ez utóbbiakról szólva ugyanakkor érdemes megjegyezni, hogy a szultán valószínüleg személy szerint is nyitott volt - mai szóhasználattal élve, de a középkori keretek között értelmezve - a más vallásúakkal való dialógusra.

A kereszténységhez való személyes viszonyát azonban legfőképp neveltetése befolyásolhatta. AlKámil fiatal korának egy részét ugyanis egy keresztény fejedelem, I. (Oroszlánszívü) Richárd angol király udvarában töltötte, aki Szicília királynőjének, Johannának volt a testvére. Egy Szaladin és Richárd közötti egyezség révén a dél-itáliai királynő majdhogynem al-Ádillal lépett frigyre, így amíg a házasság lehetősége reálisnak tünt, addig az utóbbi fia, a későbbi szultán, al-Kámil az angol királyi

\footnotetext{
${ }^{3}$ Bozsóky Pál Gerő pont az eredeti céljuktól eltérített keresztes hadjáratok kapcsán utalt rá, hogy a Szent Sír visszaszerzésért indított hadjáratokat minden esetben a pápa hirdette meg, ő nevezte ki annak szervezőjét, személyesen kérte a hadba indulást, valamint kizárólagos joga volt meghatározni a célkitűzéseket. Bár gyakran megtörtént, hogy a keresztes vezéreknek más elképzeléseik voltak a célokkal kapcsolatban, a had vezetését felügyelő pápai legátusnak minden esetben tájékoztatnia kellett ezekről Rómát és közvetítenie kellett felettese kritikáját is (vö. BOZSÓKY 1995, p. 253).

${ }^{4}$ Az V. keresztes hadjárat első, 1217 és 1218 közötti szakaszában részt vett II. András magyar király is. Bár ő a maga seregével már nem volt ott Damietta ostrománál, de a király megbízásából, Simon nádor vezetésével egy magyar különítmény a keresztesek oldalán küzdött a városért (vö. BOZSÓKY 1995, pp. 100-101).
} 
udvarban tölthette fiatal évei egy részét lovagként (vö. MOSES 2009, pp. 67-68; RUNCIMAN 2002, pp. 754-755). Ez az információ ismét csak egy újabb szempont lehet az al-Kámil személyiségét formáló tényezők vizsgálatánál, azonban - és ezt ismét hangsúlyozni kell - uralkodóként még az egyiptomi szultán sem tehetett meg bármit, amit éppen humánusnak vagy személy szerint etikailag helyesnek gondolt. Itt elég csak arra utalni, hogy al-Kámil mégiscsak egy muszlim birodalom uralkodója volt, és ez a körülmény nem minden esetben tette lehetővé az ö számára sem, hogy az uralma alatt élö keresztények szempontjait is figyelembe véve, a béke és a megértés jegyében kormányozza országát. Érdemes figyelembe venni, hogy lehettek körülötte olyan hatalmasságok is, akik a szultáni udvarban időről-időre megpróbálhatták a szultánt a Krisztust követők ellen hangolni. A fentieket már csak azért is fontos elöre rögzíteni, mert ahhoz, hogy az egyiptomi szultán és Szent Ferenc találkozója szerencsésen végződjön, több körülménynek is abba az irányba kellett hatnia, hogy az utóbbi a legrosszabb esetben is ép bőrrel ússza meg az eseményt. Ehhez azonban al-Kámil feltételezett humanizmusán és toleranciáján túl szükség volt arra is, hogy az aktuális hadi helyzet és a muszlim előkelők közötti hatalmi viszonyok megfelelőképpen alakuljanak, és a szultán uralkodóként szintén érdekelt legyen vendége biztonságának megőrzésében, vagy legalábbis politikai szempontból ne tartsa feltétlenül szükségszerủnek Ferenc halálát.

\section{Damietta ostromának kezdetétöl a szultán békeajánlatáig (1219. február-1219. szeptember)}

Ami a keresztes és a muszlim sereg közötti hadmüveletek állását illeti, az 1219 februárjának elején inkább az előbbinek kedvezett, hiszen - bár a keresztes tábort járvány tizedelte és egy áradás is elöntötte - a leginkább Pelagius Galvani bíboros, pápai legátus által vezetett keresztes hadnak ekkor sikerült teljesen körülzárnia Damietta városát. ${ }^{5}$ A jelentős fegyverténnyel kapcsolatban ugyanakkor fontos megjegyezni, hogy az ostromzár létrejötte elsősorban nem a keresztes had egyértelmü fölényének volt köszönhető. Míg korábban egyik hadviselő félnek sem sikerült kikényszerítenie kitüzött céljának elérését, 1219 elején a támadóknak erre jó lehetősége adódott. Korábbi pozícióját feladva ugyanis al-Kámil hadserege váratlanul visszavonult, és így már csak a Damiettát védő helyőrséggel kellett szembenéznie a kereszteseknek. A hadi helyzet hirtelen változása mögött egy alKámil elleni összeesküvést találunk: a szultán környezetéhez tartozó egyik főember, Imád ad-Din Ahmad Ibn al-Mástub (röviden és a továbbiakban: al-Mástub) úgy gondolta, helyesebb lenne, ha inkább az uralkodó egyik testvére, al-Fáiz kerülne Egyiptom trónjára. Mindez történt éppen akkor, amikor al-Kámil a Nílus-delta kulcsának, Damiettának megtartásáért küzdött a keresztesekkel, így a szultánnak döntenie kellett, és ő az ellene irányuló összeesküvést tartotta súlyosabb problémának. Hogy a helyzet valóban kritikus lehetett, azt alátámasztja az is, hogy Szíriából még al-Muazzam is az egyiptomi uralkodó segítségére sietett a pártütők ellen, pedig az ő szerepe máskülönben inkább a szentföldi keresztes államok állandó veszélyeztetése volt. A damaszkuszi és az egyiptomi uralkodó egyesült seregei végül úrrá lettek a kihíváson. Al-Mástub börtönbe került, al-Fáiz sorsa pedig a számüzetés lett volna, ha ennek helyszínére tartva el nem éri végezete és rejtélyes körülmények között meg nem hal (vö. RUNCIMAN 2002, p. 757; MOSES 2009, pp. 91-94). Ez utóbbi pontos körülményeire ezúttal nem térhetünk ki, azonban az eset ismét rávilágít arra, hogy al-Kámilnak, a korabeli muszlim világ egyik leghatalmasabb uralkodójaként olykor nehéz döntéseket kellett meghoznia. A kérdés nagy vonalakban az lehetett az egyiptomi szultán számára, hogy veszni hagyja a Nílus-delta központját, aminek eleste után a keresztes had akár Kairót is veszélyeztetheti, és akkor egész Egyiptomot elveszítheti; vagy a pártütőket igyekszik elszigetelni addig, amíg nem sikerül kiverni az észak felöl

\footnotetext{
${ }^{5}$ A pápai flottával a keresztes hadhoz csatlakozó Pelagius az ekkor harcosokat küldő államok között a legnagyobb tekintéllyel bíró római kúriát képviselte, így a bíboros az egész hadsereg irányítására is igényt tartott. Mindez folyamatos konfliktusokat eredményezett közte és a tekintélyben utána következő I. János jeruzsálemi király között (vö. RUNCIMAN 2002, pp. 755-756).
} 
támadókat az országból. Úgy tűnik, az utóbbihoz nem állt rendelkezésre a szükséges haderő, ezért ahogy korábban, úgy ezt követően sem sikerült egyik napról a másikra kikergetni a kereszteseket Egyiptomból. Az összeesküvés azonban egyébként is veszélyesebb kihívásnak tünt, mint az észak felől támadó hadsereg. Ezt valószínüleg al-Muazzam is így gondolhatta, ha ő maga indult testvére megsegítésére.

Az összeesküvőkkel való leszámolást követően al-Kámil testvére, al-Muazzam, látszólag szokatlan lépésre szánta rá magát. Az év márciusában az Ajjúbida Birodalom nyugati felében uralkodó damaszkuszi szultán elkezdte leromboltatni Jeruzsálem falait. A döntés szoros összefüggésben volt a muszlimok számára veszni látszó Damietta körüli hadi helyzettel, ugyanis - bár az ostromgyürü bezárulása előtt al-Kámil még ki tudta menteni a városból 8000 emberét - az alatt a pár hét alatt, amíg a két testvér a pártütés leverésével volt elfoglalva, a keresztes sereg olyan előnyre tett szert a nílusi hadszíntéren, amelyet az egyiptomi szultán már nem tudott a maga javára fordítani. Ebben a helyzetben pedig úgy túnik, már al-Kámil sem látott más kiutat, minthogy elöbb vagy utóbb egy olyan békeajánlatot küldjön az ellenséges táborba, amelyet a keresztesek nem utasítanak majd vissza. A szultán elsődleges célja birodalmának megmentése volt, és ebből a szempontból még a muszlimok számára is kiemelkedő vallási jelentőségű Jeruzsálem átadása sem lehetett túl nagy ár ahhoz, hogy megvédje Egyiptomot maga és utódai számára. A Szaladin által több mint száz éve elfoglalt városról való lemondás azonban ebben az esetben sem lehetett végérvényes, hiszen egy muszlim hadsereg így a siker reményével próbálkozhatott volna a békeajánlat feltétele szerint immár falak nélküli, védtelen Jeruzsálem visszaszerzésével a későbbiekben (vö. RUNCIMAN 2002, p. 758; MOSES 2009, pp. 94-96).

Bár a körülzárt Damiettához később visszatért al-Kámil hadserege, és a város védőinek is elég ellátmány állt még a rendelkezésére, a szultán hadserege már nem tudta a keresztes ostromzárat szétverni, s folyamatos járványok tizedelték a bent rekedteket is. Bizonyosan tudni lehetett, hogy a Nílus-delta kulcsa hamarosan el fog esni. Erre talán már hamarabb is sor kerülhetett volna, ha Pelagius bíboros és I. János király nem vitatkozik folyton a sereg vezetésével kapcsolatos kérdéseken, és a keresztes had jobban kihasználja azt a pár hétnyi időszakot, amíg a szultán az ellene szervezkedő pártütőkkel volt elfoglalva. Más oldalról, amennyiben a támadó hadsereg helyzetét tekintjük, akkor már csak a vezetési problémák miatt sem lehet egyértelmüen kijelenteni, hogy döntő fölényben voltak a keresztesek. Úgy tünt, hogy Damietta körül olyan patthelyzet alakult ki a két sereg között 1219 augusztusában, amelyben mégis inkább a támadók voltak jobb helyzetben. ${ }^{6}$ Celanói Tamás, Szent Ferenc egyik legendaírója szerint ekkor történt, hogy a rendalapító a sereget vissza akarta tartani egy meggondolatlan ütközettől, amely azonban mégis bekövetkezett, és a keresztes had súlyos vereséget szenvedett (vö. 1Cel 30). Természetesen Szent Ferenc egyik legendájának autentikus történeti forrásként való felhasználása csak erős kritikával lehetséges, amihez az ezt megerősítő más dokumentumok hiányoznak. ${ }^{7}$

Ami valószínüsíthető, az Ferencnek és társainak jelenléte a keresztes táborban 1219 augusztusában. ${ }^{8}$ Hogy a béke elkötelezett híveként mit csinálhatott a rendalapító a hol túlságosan fellelkesült és csatára kész, hol pedig az ellátási gondok és az elvártnál lassúbb előrenyomulás miatt reményüket vesztő keresztesek között, azt a történeti források hiányában nem tudhatjuk. Azonban,

\footnotetext{
${ }^{6}$ Bozsóky Pál Gerő szerint a keresztesek és a szultán hadserege közötti 1219. július 20-i, 31-i és augusztus 19-i csatákat követően vált egyértelmüvé, hogy egyik had sem képes egyértelműen a másik fölé kerekedni. Így a ferences rendtörténész inkább a két fél közötti kölcsönös kapcsolatkeresésre helyezte a hangsúlyt, amelynek során titokban tárgyalások is folyhattak a hadban állók között (vö. BOZSÓKY 1995, p. 101).

${ }^{7}$ Míg Bozsóky Pál Gerő az augusztus 19-i, addig Steven Runciman az augusztus 29-i dátumot említi az ütközet időpontjaként (vö. BOZSÓKY 1995, p. 101; RUNCIMAN 2002, p. 758).

${ }^{8}$ Szent Ferenc egy hónappal korábban már, 1219 júliusában érkezett Akkonba, majd pár nap múlva utazott tovább Egyiptomba. A vele utazó testvérek közül még Barbaro, Illuminato és Leonard nevét ismerjük, de lehettek többen is a rendalapító kíséretében (vö. BOZSÓKY 1995, p. 10; MOSES 2009, p. 102).
} 
még ha egyértelmüen nem is lehet kijelenteni, de valóban elképzelhetö, hogy a Pelagius bíboros és I. János király közti vitákat megunt sereg meggondolatlanul bocsátkozott ütközetbe. A vereség azonban bármilyen nagy is volt, al-Kámil nem tudta kihasználni pillanatnyi előnyét, hogy megsemmisítő csapást mérjen a szemben állókra. A muszlim sereg valójában a keresztes hadhoz hasonló utánpótlási problémákkal küzdött, al-Muazzam mihamarabb vissza kívánt térni Szíriába, és az Ajjúbida-dinasztián belül továbbra is súlyos belső ellentétek feszülttek. Mindez továbbra sem tette lehetővé al-Kámil számára, hogy a teljes muszlim világot mozgósítsa a támadók ellen (vö. RUNCIMAN 2002, pp. 758759).

A számára szerencsésen végződő csata után al-Kámil 1219 szeptemberében megtette békeajánlatát. A szultán egyrészt fegyverszünetet kért, másrészt felajánlotta Jeruzsálem és a Szaladin által elfoglalt szentföldi területek átadását a békéért és a támadók Egyiptomból való távozásáért cserébe (vö. BOZSÓKY 1995, p. 102; RUNCIMAN 2002, p. 759). A fegyverszünet természetesen jól jött a kereszteseknek is, de a Szent Városra vonatkozó ajánlatot visszautasították, és ismét éles vita kezdődött a pápai legátus és a jeruzsálemi király között a szultán üzenetével kapcsolatban. Ugyanakkor fontos tudni, hogy a kedvező ajánlat ellenére is a hadjárat folytatása mellett kardoskodó Pelagius bíborosnak erős érvei voltak álláspontja mellett: a Jordánon túli területek birtoklása nélkül a megszerzett térség rövid időn belül ismét muszlim kézre került volna, és az olasz kereskedővárosok is inkább a számukra nagy haszonnal kecsegtető Damietta megszerzése mellett lobbiztak (vö. RUNCIMAN 2002, p. 760).

\section{Szent Ferenc és al-Kámil szultán találkozása}

\section{A találkozó előzményei (1219. augusztus-szeptember)}

Izgalmas eredményre lehetne jutni, ha elképzelnénk, hogy Szent Ferenc és al-Kámil találkozója a szultán békeajánlatának elküldését követően történt, így az előbbi akár ismerhette is az ajánlat tartalmát, és ebben az esetben a rendalapító jó taktikai érzékkel még a szultánt is megerősíthette volna szándékában. Sajnos azonban Ferenc útjáról csak annyit tudunk, hogy a keresztes sereget ért augusztusi vereség után történt, és al-Kámil első békeajánlatának időpontját is csak hozzávetőlegesen ismerjük (1219. szeptember). ${ }^{9}$ Ugyanakkor szintén fontos megjegyezni, hogy még ha Szent Ferenc esetleg ismerte is a szultán békeajánlatát, a béke hirdetésének elkötelezett híveként az ő számára végső soron a fegyveres konfliktus lezárása lehetett az elsődleges cél. Így gyakorlatilag kizárható, hogy a rendalapító valamilyen taktikai szempontot figyelembe véve kérte Pelagius bíboros engedélyét az ellenséges tábor felkeresésére. Ami ellenben nagyon is elképzelhetö, az Szent Ferenc tudatos döntése az időpont kiválasztása kapcsán. Nem tudjuk, pontosan mióta lehetett már a táborban, de minden bizonnyal azt ő maga is jól tudhatta, hogy nem lehet bármilyen körülmények között megkockáztatnia a veszélyes küldetést. Erre nyilvánvalóan nem kerülhetett sor sem egy ütközet kellős közepén (a foglyul

\footnotetext{
${ }^{9}$ A keresztes hadjáratok történetéről az 1950-es években több kötetes, eseménytörténeti szempontból mind a mai napig jól használható munkát író cambridge-i középkortörténész professzor, Steven Runciman al-Kámil szeptemberi ajánlata kapcsán Oliver Paderborn, 13. századi gestaíróra hivatkozik, aki a Damietta körüli harcok történetének egyik elsődleges forrásául szolgáló Historia Damietta című krónikát írta (vö. PETERS 1971, pp. 8586; RUNCIMAN 2002, p. 759). Runciman álláspontjának némileg ellentmond a Ferenc és a szultán találkozásáról önálló monográfiát író Paul Mosesé. A nem gyakorlott középkorkutató és a történészi precizitást olykor mellőző Moses szerint már 1219 márciusában, Jeruzsálem falai lerombolásának kezdetekor elküldte alKámil békeajánlatát a keresztes táborba. Moses az általa másodiknak tartott szultáni ajánlat időpontját teszi 1219 szeptemberének elejére (vö. MOSES 2009, p. 94; pp. 120-121). Az utóbbi szerző ugyanakkor nem jelöl meg pontosan forrásokat müve hivatkozásaiként, így Steven Runciman következtetését fogadjuk el az első szultáni ajánlat időpontjával kapcsolatban. Az ennek forrásául szolgáló, fentebb idézett középkori krónika is alapvetően inkább egy 1219 őszi dátumot valószínüsít.
} 
ejtés esetét leszámítva), sem pedig akkor, amikor a másik fél kellően magabiztosnak érzi magát a békét hirdető szó elől való elzárkózáshoz. Mint fentebb már volt róla szó, al-Kámil valószínüleg már 1219 márciusa óta készült arra, hogy valamilyen formában békét kérjen, és hajlandósága nem csökkent még augusztusi győzelmének ellenére sem. Ha bizonyosan nem is tudható, de elképzelhető, hogy függetlenül a szultán konkrét terveinek ismeretétől, az ütközet utáni helyzetet Szent Ferenc kedvezö alkalomként értékelte békemissziójának végrehajtásához. Ehhez azonban előbb meg kellett győznie a keresztes táborban lévő legmagasabb rangú egyházi méltóságot, Pelagius bíborost is.

A rendalapító és a bíboros közti találkozást a korabeli források közül a francia Ernoul krónikája örökítette meg. A később, 1227 és 1229 között, írt munkában a szerző név nélkül ír két egyházi személyröl, akik Damiettánál engedélyt kértek a pápai legátustól ahhoz, hogy átmenjenek a szultánhoz. A szöveg kétséget kizáróan Ferencre és társára, az Illuminato néven ismert testvérre utal. A krónika szerint Pelagius mindenekelőtt fontosnak tartotta közölni az elé járulókkal, hogy soha nem térnének vissza a muszlim táborból, ha vállalkoznak a veszélyes útra, így semmilyen formában nem adhat engedélyt arra, hogy a nevében átmenjenek az ellenséghez. Amennyiben mégis útra kelnek, akkor a bíboros felhívta a ferences testvérek figyelmét, hogy kerülni kell annak látszatát, mintha ö küldte volna a testvéreket, és csak Istenbe vethetik minden reményüket. Mivel Pelagius bíboros Ernoul által megörökített - valójában nem tudni pontosan miként elhangzó - szavainak később még lesz jelentősége a ferences regula vonatkozó részének elemzésekor, így érdemes közölni a francia nyelvü krónika szövegrészének fordítását:

„Uraim, nem tudom, mit forgatnak szívükben és gondolataikban, vajon jó vagy rossz okokkal. Viszont, ha már oda mennek [a muszlim táborba], figyeljenek arra, hogy sziviüket és gondolataikat mindig az Úrra és az Istenre irányozzák." 10

\section{Szent Ferenc találkozása al-Kámil szultánnal (1219. szeptember)}

Ezt követően, valamikor 1219 szeptemberének első felében kerülhetett sor Ferenc és al-Kámil találkozójára a Fariskurnál lévő muszlim táborban, amiről a konkrétumok szintjén sajnos meglehetősen keveset tudni. Az viszont bizonyosnak tủnik, és Ernoul krónikája is utal rá, hogy Ferenc és társa pár napot eltölthettek a muszlim táborban, és volt alkalmuk megfigyelni az ott élők életmódját, illetve vallásgyakorlatát (vö. ERNOUL 2009, p. 1544). Mint arról később még lesz szó, az itt szerzett benyomásokra a rend meg nem erösített regulája vonatkozó részei, illetve a rendalapító levelei is utalnak.

Mindenekelött azonban látnunk kell mennyire eltérő módokon értelmezték különböző korszakok, különböző gondolkodásmódú emberei a találkozót. Elég csak néhány példát hoznunk erre vonatkozóan. A keresztes hadjáratban személy szerint is szerepet vállaló, Szent Ferenccel és követőivel inkább kritikus Vitry Jakab, Akkon püspöke, a következőképp írt a találkozóról 1221 szeptembere előtt írt munkájában:

„A szultán nagyon figyelmesen hallgatta [Ferencet]. Mivel azonban végül már tartott töle, hogy a seregéböl valók megtérnek Istenhez és átszöknek a

\footnotetext{
${ }^{10}$ A 12. század második és a 13. század első felében élt Ernoulról annyit tudni, hogy fegyverhordozóként, apródként szolgált a Jeruzsálemi Királyság egyik méltósága, Ibelini Balián mellett (vö. HUBER \& LEHMANN 2009, p. 1543.). A harmadiktól és az ötödik keresztes hadjáratig terjedő időszak eseményeit feldolgozó francia nyelvü krónikában a szerző a következő formában örökítette meg Pelagius Szent Ferencéknek szánt szavait:

„Seigneurs, je ne sais ce que sont vos coeurs et vos pensées, ni si elles sont bonnes ou mauvaises, et si vous y allez, prenez garde que votre coeur et vos pensées soient toujours tournés vers Dieu.”
}

(Idézi TOLAN 2007, p. 75) 
keresztények seregéhez [Ferenc] szavainak hatására, megparancsolta, hogy a legnagyobb tisztelettel és védelem mellett vezessék vissza a mieink táborába."11

Szent Bonaventura, aki 1260 és 1263 között a ferences rend miniszter generálisaként írta Szent Ferenc legendáját, már más szempontokat előtérbe helyezve írt az esetről (pl. Ferenc vértanúság iránti vágyát emelte ki ennek kapcsán). Más oldalról azonban megerősítette az akkoni püspök által írtakat.

„A szultán is csodálta Isten emberében a lélek buzgóságát és erejét. Szívesen hallgatta, söt tartóztatta öt, hogy maradjon vele. [...] [miután pedig Ferenc felajánlotta, hogy akár a tüzön is keresztülmegy bizonyítva Krisztusba vetett hitét] a szultán azt válaszolta, hogy nem meri elfogadni ajánlatát, félt ugyanis népe lázadásától." 12

Aztán eltelt néhány évszázad, és a fentebb már említett brit középkortörténész, a politikailag egyébként erősen liberális kötődésủ Steven Runciman az 1950-es években éppen csak egy bekezdés erejéig említette Szent Ferenc látogatását al-Kámilnál. A keresztes háborúk teljes történetét feldolgozó munka érintett részénél, az Ernoul krónikájára is hivatkozó neves historikus szerint a későbbi szentet a muszlim őrök valószínűleg őrültnek nézték, de a szultán már figyelemmel hallgatta.

„Elvezették al-Kámil szultánhoz, akit elbüvölt, és aki türelmesen végighallgatta kéréseit. Túlságosan jószívü és civilizált volt ahhoz, hogy megengedje, hogy a barát hitét tüzpróbával is bebizonyítsa. Azt sem kívánta megkockáztatni, hogy egy nyilvános vallási vita keserüséget keltsen." (RUNCIMAN 2002, p. 759)

Természetesen hosszan lehetne sorolni, hogy miért nem érdemes összevetni egy kortárs krónikaírónak, egy hagiográfia szerzőjének, illetve egy huszadik századi történésznek a munkáját; azonban annyi bizonyosan megállapítható, hogy egyrészt mindannyian történeti eseményként tekintettek Ferenc és al-Kámil találkozójára, másrészt mindegyik narráció inkább a pozitív hagyományhoz tartozóként számolt be erről.

A történeti emlékezetben tovább élő esemény konkrét körülményeit a források nagyobbrészt csak sejtetni engedik. A ferences rend korai történetének és a keresztes hadjáratoknak a forrásait is jól ismerő Bozsóky Pál Gerő azonban egészen konkrétan írt a párbeszédről, amelynek során Ferenc bemutatkozhatott a szultán előtt.

„Jézus Krisztus követe, aki Isten fia, a Szentháromságban a második isteni személy, aki azért jött a földre, hogy az embereket kibékítse az Atyával. Tanitásának két nagy parancsa van: az Istenbe vetett hit és az ebböl fakadó szeretet és béke."

(BOZSÓKY 1995, p. 101)

A rendtörténész által írtak az elképzelt beszélgetésnek a valószínűsíthető, eszmei tartalmát rögzítik, amelyre egyrészt a források is következtetni engednek, másrészt pedig a rendalapító által képviselt szellemiségből is következhet. Az idézetből kiindulva akár a találkozó egyes részleteit is magunk elé képzelhetjük, azonban a történeti szempontból hiteles források ezekre vonatkozóan hiányoznak; így minimálisan csak annyit állapíthatunk meg, hogy Assisi Szent Ferenc minden bizonnyal próbálhatta azt a közös pontot megtalálni a szultán elött, amelyet hite szerint al-Kámil elfogadhatott, és amely egyben a béke ügyét szolgálhatta.

\footnotetext{
${ }^{11}$ Vitry Jakab eredetileg latinul írta Historia Occidentalis néven említett munkáját, amelynek 32. fejezetében írt a találkozóról. Az idézet szövegrész német fordításban:

„Der Sultan hörte ihm sehr aufmerksam zu. Doch da er schlisslich befürchtete, Leute aus seinem Heer könnten sich auf Grund der Wirksamkeit seiner Worte zu Gott bekehren und ins Heer der Christen überlaufen, befahl er, ihn mit allen Ehren und unter Gleitschutz ins Lager der Unsrigen zurückzubringen." (VITRY 2009a, p. 1541)

${ }^{12}$ Kiemelés a legenda 2015-ös kiadásának szerkesztőjétől (BONAVENTURA 2015, pp. 125-126).
} 
Ha a történészi narráción túl a muszlimok és a keresztény térítők közötti viszonyról szeretnénk kortárs forrást olvasni, akkor érdemes ismét Vitryhez fordulnunk. Az akkoni püspök 1221 előtt keletkezett munkájában, a Historia Occidentalis néven említett krónikában azt írta Szent Ferenc és a szultán találkozásának összegzéseként, hogy a muszlimok alapjában véve meghallgatták a keresztény hitükről beszélő kisebb testvéreket mindaddig, amíg Mohamed személye nem került szóba negatív kontextusban.

„Egyébiránt minden szaracén szívesen hallgatja, ha a nevezett kisebb testvérek Krisztusban való hitükröl és az evangélium tanításáról beszélnek. Azonban amint nyíltan elkezdik Mohamedet, mint hitetlen hazug prófétát gyalázni, irgalmatlanul elverik a testvéreket, és még meg is ölnék öket, ha csodálatos módon Isten meg nem oltalmazná öket."13

Mint később még látni fogjuk, 1220 után már a ferencesek között is volt tapasztalat azzal kapcsolatban, hogy mi történik akkor, ha az iszlám tanításától eltérő tanokat hirdetnek ebben a környezetben.

A találkozó két főszereplöjéről szólva feltünik a közel azonos életkor. Az ekkor 37 éves Szent Ferenc már találkozott bíborosokkal, királlyal és pápával is, míg a két évvel idősebb al-Kámil már csak neveltetése és az országában élő keresztények miatt is jól ismerhette a nyugati kultúrát. Ezen kívül a szultán akár egy békeküldöttségnek is nézhette az elé járuló két szerzetest még akkor is, ha esetleg ekkor még nem küldte el konkrét ajánlatát a keresztesek táborába. Mint fentebb már volt róla szó, erre al-Kámil már korábban is készülhetett, így ebből a szempontból sem állt érdekében, hogy Ferencnek és kísérőjének komolyabb bántódása legyen. Az a kortárs beszámoló, amely szerint a rendalapító mindjárt az elején, már a muszlim őrséggel való találkozásánál világossá tette, hogy keresztény és a szultán elé kíván járulni szintén Vitry Jakabtól származik (vö. VITRY 2009a, p. 1541). Innentől azonban a források faggatásának már nincs különösebb értelme. Bármi is hangzott el a muszlim táborban, arról még a kortárs akkoni püspök sem tudhatott semmi biztosat. Annyi azonban mégiscsak valószínüsíthető, hogy Ferenc nem beszélhetett a keresztes sereg valamely vezérének nevében. Még ha erős kétségeink is vannak azzal kapcsolatban, hogy a későbbi krónikás, Ernoul ismerhette-e pontosan Pelagius bíboros Szent Ferencnek címzett szavait; ${ }^{14}$ még akkor is feltételezhető, hogy a testvérek valóban semmilyen felhatalmazást nem kaptak a keresztes sereg vezéreitől békeüzenet továbbítására.

Ferenc későbbi írásaiból még arra is lehet következtetni, hogy hosszabb időt, akár pár napot is eltölthetett al-Kámil táborában. Arra legalábbis mindenképpen volt lehetősége a rendalapítónak, hogy megfigyelhessen egy, a keresztényektől eltérő vallásgyakorlatot. Mint később, az 1220-ban az őrökhöz és a népek vezetőihez címzett leveleiben írta, az érintetteknek igyekezniük kell úgy hirdetni az igét vagy arra buzdítani a népet, hogy adott jelre a hívők mindenütt egyszerre imádhassák az Istent. ${ }^{15} \mathrm{~A}$

\footnotetext{
${ }^{13}$ A muszlimok és a keresztény térítők közötti viszony a következőképpen jelenik meg Vitry Jakab munkájának német fordításában:
}

„Im Übrigen hören alle Sarazenen gerne zu, wenn die genannten Minderen Brüder vom Glauben an Christus und von der Lehre des Evangeliums predigen. Sobald sie aber anfangen, offen gegen Mohammed als einen treulenlosen Lügenpropheten zu lästern, verprügeln sie die Brüdern erbarmungslos und würden sie sogar umbringen, wenn Gott sie nicht wunderbar beschützte.” (VITRY 2009a, p. 1541)

${ }^{14}$ Idézi TOLAN 2007, p. 75.

${ }^{15}$ A Levél az örökhöz (Epistola ad custodes) a következőképp szólította fel a rend vezetőit a buzgóbb vallásgyakorlat meghonosítására:

„És úgy hirdessétek és prédikáljátok az ö [Isten] dicséretét minden népnek, hogy minden órában és a harangok szavának minden megcsendülésére az egész földkerekségen minden nép dicséretes hálaadást zengjen a mindenható Istennek." (LÖR 1995, pp. 83-84) 
szorgalmazott gyakorlat igen hasonló a muszlim világban a müezzin felhívására végzett imához. Lehetséges, hogy a Szent Ferenc által szorgalmazott, a hit iránti mély elkötelezettséget kifejező és áhítatot keltő vallásgyakorlat alapimpulzusait a muszlim vallásgyakolat szolgáltatta.

Elképzelhető az is, hogy al-Kámil valóban abban a kedvezményben részesítette a keresztesek közé visszatérő testvéreket, hogy a muszlim fennhatóság alatt álló szent helyeket szabadon, adófizetés nélkül is látogathatják, amit Ferenc feltételezhetően ki is használhatott nem sokkal a találkozó után. ${ }^{16}$ A rendalapító szentföldi útjáról sajnos viszonylag keveset tudunk, de a háborús körülmények között valamely muszlim uralkodó részéről egy keresztény egyházi rendnek adott kedvezmény nyilván inkább a kivételes intézkedések közé tartozhatott, így még ha az összecsapások folytatódtak is, ennyi azonnali és kézzel fogható eredménye már ekkor lehetett a találkozónak. Szent Ferenc közvetlen céljaira a Celánói Tamás által írt életrajzában találunk utalásokat. Az életrajz kiemeli Szent Ferenc vértanúság iránti vágyát Damietta melletti veszélyes akciója kapcsán, de Vitry Jakab inkább annak eredménytelenségére hívta fel a figyelmet (vö. BONAVENTURA 2015, pp. 123-125; 1Cel 57; VITRY 2009b, p. 1537). A forrásokat és az V. keresztes hadjárat szakirodalmát összevetve azonban inkább úgy tünik, hogy a béke ügye mellett mindenkor elkötelezett Ferencnek egyszerüen ekkor, ebben a feszült helyzetben, a keresztesek részéről egy vesztett ütközet után és egy továbbra is szorult helyzetben lévő muszlim uralkodó békeajánlatának küszöbén nyílt lehetősége arra, hogy megkockáztassa a két tábor közötti veszélyes utat. Ilyen viszonyok mellett az egyértelmü és azonnali siker Ferenc számára a két fél közötti béke lett volna. Ennek megkötése azonban váratott magára, mivel a keresztes sereg vezetői 1219 szeptemberében még lehetségesnek tartották a hadjárat győztes befejezését, és al-Kámil birodalmának szétzúzását.

\section{Az V. keresztes hadjárat elhúzódása}

\section{Damietta elfoglalása és a keresztes had elörenyomulása (1219-1221)}

A hadjárat kellös közepén, 1219 második felében, kizárólag Pelagius bíboroson és I. János jeruzsálemi királyon múlt al-Kámil októberben megismételt békeajánlatának elfogadása. Várható volt, hogy a szentföldi keresztes állam uralkodója és III. Honorius pápa legátusa között ismét kiújuljon a régóta tartó konfliktus. Könnyen érthető, hogy az elöbbinek fontosabb volt, hogy az Ajjúbida Birodalom szorításában lévő állama végre visszaszerezze annak egykori fővárosát, Jeruzsálemet - nem is szólva a visszaszerző személyét övező dicsőségtől, amelyet ebben az esetben I. János szintén magának követelt volna. Vele ellentétben Pelagiusnak nagyobb szabású tervei voltak, melyek a Nílusdelta megszerzését részesítették előnyben. Ennek megfelelően a nagyobb befolyással bíró pápai legátusnak sikerült elérnie a hadmủveletek folytatását, amelynek közvetlen eredménye nem is maradt

A valószínüleg az Ibériai-félszigeten lévő keresztény fejedelmeknek küldött Levél a népek vezetőihez (Epistola ad populorum rectores) címü írásában hasonló javaslatot tett Ferenc:

„És igyekezzetek a rátok bízott népben olyan nagy tiszteletet ébreszteni az Úr iránt, hogy esténként hírvivö útján vagy más módon az adott jelre az egész lakosság zengjen dicséretet és adjon hálát a mindenható Úristennek.” (LNVEZ 1995, p. 85)

\footnotetext{
${ }^{16}$ A jeruzsálemi ferences kusztódia levéltárában is kutatásokat végző Bozsóky Pál Gerő szerint a fennmaradt 13. századi iratok között több, muszlim hatalmasságok által kiállított oltalomlevél (firmán) is van. Az iratok léte egyben azt is jelzi, hogy a szentföldi ferencesek jelenléte már a rendtörténet korai időszakában összeforrhatott a szent helyek őrzésével. Szintén ugyanő említi munkájában, hogy Rukn ad-Dín Bajbarsz (Bozsókynál I. Zaher Bihars), 1260 és 1277 között uralkodó egyiptomi szultán újabb firmánt állított ki a ferencesek számára, amelyben megengedte, hogy a szent helyeket látogassák és azokban hitük szerint imádkozzanak (vö. BOZSÓKY 1995, p. 102). Az értelmezés szerint így a muszlim uralkodók által a ferenceseknek adott kiváltságok már több évtizede érvényben lehettek a 13. század közepén, ami megerösíti, hogy azok akár Ferenc korából is származhatnak.
} 
el. Alig egy-két hónappal Szent Ferenc és a szultán találkozója után, 1219. november 5-én Damietta teljesen a keresztesek kezébe került. A még így is komoly utánpótlással rendelkező, de nagyon legyengült és járványoktól tizedelt lakosságú városban megkezdődött a fosztogatás, amelyről minden bizonnyal Ferenc is első kézből értesülhetett (vö. HOEBERICHTS 1997, pp. 58-59; RUNCIMAN 2002, pp. 760-761).

A győzelem után a keresztesek szeme előtt már új cél lebegett: Kairó elfoglalása és ezáltal al-Kámil hatalmának teljes megdöntése. Ehhez azonban egy olyan energikus vezetöre lett volna szükség, aki a sereg előtt megfellebbezhetetlen tekintéllyel bír, és riválisait távol tudja tartani a lényegi döntésektöl. Bár kétségtelen, hogy a pápai legátusnak volt a legnagyobb befolyása a keresztes had vezetésében, ez azonban még mindig kevés volt ahhoz, hogy Pelagiusnak minden más véleményt felülíró tekintélye legyen a főbb kérdéseiben. Így aztán a hosszas ostrom után elfoglalt város feletti joghatóság körül ismét vita bontakozott ki, amelynek eredményeként az a kompromisszum született, hogy I. János lehet Damietta ura egészen addig, amíg II. Frigyes, német-római uralkodó beígért serege meg nem érkezik Egyiptomba. Az erősítés érkezésének reménye megtette hatását, így még 1220 márciusában is, amikor al-Muazzam, az egyiptomi szultán fivére al-Kámil helyzetén könnyítendő ostrom alá vette a Jeruzsálemi Királysághoz tartozó Kaiszareia és Atlit várát, Pelagius bíboros még mindig harc folytatása mellett volt. A német-római császár seregének egy része 1221 tavaszán Bajor Lajos vezetésével meg is érkezett Egyiptomba, azonban a bonyodalmakat fokozandó, az újonnan jöttek csak I. János utasításait voltak hajlandóak követni egészen addig, míg maga II. Frigyes meg nem érkezik. A német területek és Szicília felett is regnáló uralkodó ígéretének betartása a pápával való viszony függvénye is volt, így elviekben csak 1220 novembere, Rómában történő császárrá koronázása után gondolhatott szavának beváltására. ${ }^{17}$ Ekkor azonban a kereszteseknek küldött jelentősebb katonai erősítés kérdése már III. Honorius pápa szerint is annyira bizonytalanná vált, hogy maga tanácsolta Egyiptomban lévő legátusának, hogy ezt követően már ne utasítsa vissza gondolkodás nélkül al-Kámil következő békeajánlatát, hanem azt előbb feltétlenül ismertesse meg Rómával. Pelagius azonban - a pápa üzenetét figyelmen kívül hagyva és bízva a további erősítés érkezésében, amelynek segítségével összezúzhatják a szultán birodalmát - már csak utólag tájékoztatta az egyházfőt al-Kámil újabb, 1220 nyarán tett ajánlatáról, amelyben a muszlim uralkodó lényegében megismételte 1219 őszi békefeltételeit. Miközben II. Frigyes hadba szállásának híre továbbra is késett, a részleges erősítés megérkezése ismét feltüzelte a keresztesek vezetőit, így a további előrenyomulás mellett döntöttek (vö. RUNCIMAN 2002, pp. 764-765).

A keresztesek oldalán ekkor rendelkezésre álló katonai erő a középkori viszonyokat tekintve egészen elképesztő méretü lehetett. Az egykori krónikák mintegy 630 hajóról, 5000 lovasról, 4000 ijászról és 40.000 gyalogosról szólnak (vö. RUNCIMAN 2002, p. 765). Egy ekkora sereg ellátása ebben a korban komoly nehézségekbe ütközött. Abban az esetben, ha a harcosokra is bízták volna saját ellátásuk előteremtését, mindenképpen figyelembe kell venni, hogy egy, már évekkel azelőtt hadszíntérré vált területen kellett volna eleget fosztogatniuk saját maguk számára. Máskülönben az utánpótlás csak tengeri úton érkezhetett, és a Damiettában talált, a források szerint bőséges készletek sem biztos, hogy elegendőek lettek volna egy ekkora sereg hosszú távú ellátására, így a haderő méreteivel kapcsolatos biztos információ hiányában, csak annak szokatlan nagyságát érdemes megemlíteni. ${ }^{18}$ Mindezt figyelembe véve adódik a feltevés, hogy az utánpótlási nehézségeket más úton

\footnotetext{
${ }^{17}$ A Német-Római Birodalmon belüli trónviszály miatt II. Frigyest először csak Mainzban koronázták a birodalom császárává 1212-ben, majd három évvel később, immár a hagyományos koronázóvárosban, Aachenben már az összes német fejedelem elismerte uralkodóként. Ekkor tett ígéretet arra is, hogy hadjáratot indít a Szent Sír felszabadítására. Az ígéret betartására azonban úgy tűnik, hogy II. Frigyes egészen római császárra koronázásáig, 1220 novemberéig nem gondolt, és még ezt követően is halogatta a hadba vonulás idejét (vö. BOZSÓKY 1995, p. 105; MOLNÁR 2004, pp. 69-70).

${ }^{18}$ Damietta elfoglalásához és az ott talált utánpótláshoz lásd RUNCIMAN 2002, pp. 760-761.
} 
talán egyébként sem tudták volna megoldani a keresztes vezérek, csak a további előrenyomulással és területszerzéssel. A középkori hadviselés velejárójaként ugyanakkor feltétlenül szólni kell arról is, hogy a hadra kelt tömeg nem egy mai értelemben vett katonai fegyelemhez szoktatott, erősen hierarchikus rend szerint felépülö hadsereg keretein belül teljesített szolgálatot. A hadjárathoz csatlakozó kisebb-nagyobb fejedelmek és a csapatukhoz, seregükhöz tartozók igyekeztek a maguk hasznára is fordítani ténykedésüket, így a harci dicsőség megszerzése mellett a személyes vagyon gyarapítása és az öncélú kalandvágy szintén komoly motivációt jelenthetett a „kereszt felöltésénél”. Így, figyelembe véve a harcosok fegyelmezetlenségét és az esetleg elmaradó zsákmány miatti elégedetlenséget, az újonnan érkezők elől valószínűleg nem lett volna tanácsos elzárni a vagyon és a dicsőség utáni vágy kielégítésének lehetőségét, és könnyen lehet, hogy erre egyébként sem lett volna lehetőség. Más oldalról, a régóta a seregben harcoló keresztesek a megérkező erősítés hírére ismét erőt meríthettek a harchoz, így az Egyiptom elfoglalásával kapcsolatos nagyszabású tervek Pelagius bíboros elképzeléseitől függetlenül is újfent felerősödhettek.

\section{A keresztes sereg veresége Bahr asz-Szagírnál és az V. keresztes hadjárat vége (1221)}

Al-Kámil hadserege egyelöre hátrált, és még az a hír is elterjedt a keresztes táborban, hogy a szultán Kairót is hátrahagyva menekül. Ha mindez nem is volt igaz, az kétségtelen, hogy muszlim oldalról ismét az Ajjúbida-családtagoknak, al-Muazzamnak és al-Asrafnak a segítéségére volt szükség a várható ütközet megvívásához. Az ezen az oldalon álló teljes haderő nagyságáról nincsenek megbízható adatok, mindenesetre van olyan szerző, aki szerint itt is közel 40.000 főről lehetett szó. ${ }^{19} \mathrm{~A}$ hosszas viták után a továbbnyomulás mellett döntő keresztes sereg végül 1221. augusztus 24-én találta szembe magát al-Kámil haderejével Bahr asz-Szagír mellett, miközben a helyszínre érkező muszlim erősítés a keresztesek hátába került, és elvágta a Damiettába való visszavonulás útját. Mire a keresztes vezérek rájöttek, hogy bekerítették őket, már késő volt. Az Ajjúbida-hadsereg teljesen körülvette őket, al-Kámil pedig megnyitotta az éppen áradó Nílus gátjait. A teljesen felázott talajon a Damiettából nagy reményekkel továbbvonuló had már menekülni sem igen tudott. A keresztesek olyan súlyos helyzetbe kerültek az őket körülvevő ellenség csapásai, a készletek elvesztése és a sereg egyre fokozódó demoralizáltsága miatt, hogy augusztus 28-án Pelagius bíboros követeket küldött al-Kámilhoz, hogy a békefeltételek felől érdeklődjön. Bár Damietta továbbra is a keresztesek kezén volt, és a városban elegendő ellátmány lehetett egy ostrom átvészeléséhez, világossá vált, hogy hosszabb távon semmiképpen nem lehet megtartani a Nílus-delta központját. Ebben a helyzetben már a pápai legátusnak is be kellett látnia, hogy a nagy célokat kitüző hadjárat teljes kudarccal végződött, és el kell fogadni a szultán feltételeit. Bár al-Kámil elvileg kihasználhatta volna a lehetőséget a keresztes had teljes megsemmisítésére, mégsem ez történt. Az Egyiptomra támadóknak el kellett hagyniuk Damiettát, a nyolc évre szóló fegyverszünetet II. Frigyes császárnak is jóvá kellett hagynia, és a város átadásáig a kereszteseknek túszok átadásával kellett szavatolniuk, hogy valóban betartják ígéretüket. Cserébe al-Kámil átadta a Szent Kereszt nála lévő darabjait, és fogolycserére is sor került. Pár nap múlva, 1221. szeptember 8-án a szultán bevonult Damiettába, a keresztesek jó része pedig hajókon visszatért hazájába (vö. RUNCIMAN 2002, pp. 765-766.). A békefeltételek szokatlanul enyhének tünhettek ahhoz a több éven át tartó súlyos fenyegetéshez képest, amit a keresztes had jelentett al-

\footnotetext{
${ }^{19}$ Paul Moses egy becsült számra utal a Ferenc és al-Kámil találkozását feldolgozó munkájában, amikor 1221 augusztusáról írva közel 40.000, a muszlim haderőben harcoló lovast említ. Bár a monográfia nem sorolható a történeti szakmunkák köze, de a szerző rendre hivatkozik a középkor kutatók által is használt forrásokra. Ugyanakkor Moses könyvének az egyesült muszlim hadsereg méretére vonatkozó résznél megadott, a keresztes hadjáratok nyugati és keleti forrásait több kötetben feldolgozó francia forráskiadvány hivatkozott oldalán nem szerepel semmilyen konkrét számszerü érték. A forráskiadvány vonatkozó oldalai Abul Fida 14. századi államférfi, történetíró arab nyelvü munkáját idézik az 1220-21-es évek eseményeivel kapcsolatban (vö. MOSES 2009, p. 167; FEDA 1872, p. 96).
} 
Kámil számára. Itt természetesen ismét meg kell jegyezni, hogy nem tudni, mennyiben következtek a fenti kitételek a szultán személyiségéből, műveltségéből, vagy éppen feltételezett emberségéből. Annyi mindenesetre valószínüsíthető, hogy - ahogy majd minden jelentősebb történelmi esemény esetében az V. keresztes hadjárat végét jelentő megállapodás kapcsán is több szempontot kell figyelembe vennünk, ha az okokat kutatjuk. Mindenekelőtt érdemes tudni, hogy az események felkorbácsolták az Egyiptomban élő keresztények elleni muszlim közhangulatot, így a háború folytatásának valószínűleg nem lett volna akadálya a harci láz lankadása erről az oldalról, és az addig viszonylag toleráns szultán is ekkor már komolyabb rendelkezéseket hozott a Krisztust követőkkel szemben (adóemelés, templomok lerombolása) (vö. RUNCIMAN 2002, p. 767). Ennél többet azonban az egyiptomi uralkodó sem tehetett. Hogy az uralkodócsalád többi tagja al-Kámil segítségére siethetett 1221-ben, az többek között azért is volt lehetséges, mert a közel-keleti térségben ekkor Egyiptom volt a leginkább kritikus pont az egész Ajjúbida Birodalom szempontjából, s a családon belül sem volt éppen olyan nézeteltérés, ami belülről bomlasztotta volna a Közel-Kelet nagy részét is magába foglaló térséget. Mindez azonban csak egy rövid időszakot jelentett, amelyet ki lehetett használni a keresztesek kiüzésére, és még ebben az esetben sem volt biztos a győzelem. Más oldalról azonban, keleten már számolni kellett a terjeszkedő Mongol Birodalommal, amely ezt a térséget is fenyegette, így várható volt, hogy rövid időn belül ismét komoly háborús kihívással kell szembenéznie az Ajjúbidáknak. AlKámilnak is érdeke volt, hogy mihamarabb békét kössön a Nyugattal legalább átmenetileg. Valószínúleg a szultán is azt szerette volna leginkább elérni, hogy ne jelenjen meg újabb, nyugatról érkező had a térségben az elkövetkező évtizedekben. Ehhez azonban egy olyan támadó hadjáratra lett volna szükség, amely nemcsak a szentföldi keresztes államokat veszi célba, hanem egész Európa számára is komoly veszélyt jelent. Az ehhez szükséges erőforrásokkal azonban az Ajjúbida Birodalom egésze sem rendelkezett, s a bonyolult családi viszonyok sem tették volna lehetővé a teljes összefogást.

A fentiek alapján így al-Kámilnak bármikor számítania kellett egyrészt az Ajjúbida Birodalmon belüli kényes egyensúly felborulására, másrészt pedig a külső támadásra is. Hat évvel később miközben az új pápa, IX. Gergely a szentföldi hadjárattól való húzódozás indokával ki is közösítette ${ }^{20}$ - II. Frigyes császár már készen állt a háborúra a Szentföldért, és ugyanebben az évben az egyiptomi szultán éppen harcban állt testvérével, al-Muazzammal is. Mivel az exkommunikáció miatt a császár nem számíthatott a szentföldi lovagrendek segítségére és a szultán sem akart két tủz közé szorulni, így Frigyes 1228 nyarán történt hadba szállása előtt két évvel már tárgyalások kezdődtek a két uralkodó között. Mire azonban a császár a Szentföldre ért, al-Muazzam már halott volt, így II. Frigyes és alKámil ott állt egymással szemben, miközben továbbra is inkább a háború elkerülésében voltak érdekeltek. Végül, hogy a muszlim és a keresztény világ legnagyobb uralkodói megszabaduljanak egymás közelségétől az 1229. februári, jaffai egyezményben al-Kámil lényegében lemondott NyugatGalileáról (Jeruzsálem, Názáret, Betlehem, Monfort, Toron és Szidón városáról). A térségbe természetesen ez a megoldás sem hozhatta el a tartós békét. Egyrészt a megállapodás csak tíz évre biztosította a két fél közötti fegyvernyugvást, s II. Frigyesnek egyébként vissza is kellett térnie Európába (bár annyit még megtett, hogy a kiátkozás ellenére jeruzsálemi királlyá koronázta saját magát). Az egymással folyton vitában álló keresztes államoknak a császár serege nélkül már nem volt ereje a város megvédésére, így egy muszlim had harc nélkül foglalhatta vissza Jeruzsálemet 1241-ben. Ezt azonban al-Kámil már nem érhette meg, az egyiptomi szultán 1238. március 9-én távozott az élők sorából (lásd BozsóKY 1995, pp. 104-109; RUNCIMAN 2002, pp. 768-797). Bár a 13. század második

\footnotetext{
${ }^{20} \mathrm{Az}$ 1227-ben pápává választott IX. Gergely még ugyanebben az évben felhívta II. Frigyes figyelmét egy újabb keresztes hadjárat megindításával kapcsolatos, 1215-ös ígéretének megtartására. Mivel a német-római császár egy pestisjárványra hivatkozva továbbra is halasztotta a hadba szállás idejét, így a pápa 1227. augusztus 29-én kiközösítette a máskülönben Róma hatalmi törekvéseire is veszélyesnek tekintett Frigyest az egyházból (vö. BOZSÓKY 1995, p. 105; RUNCIMAN 2002, pp. 772-774).
} 
felében még indultak nyugatról hadjáratok a Szentföldre, azonban a következö évszázadban már egyértelmúen a Keleté volt a kezdeményezés. Előbb Konstantinápoly irányába, majd észak felé a Balkánon megindult az oszmán terjeszkedés.

\section{Szent Ferenc hazatérése és a tapasztaltak hatása világképére Összegzés}

\section{A ferences rend első vértanúi és a meg nem erősített regula 16. fejezete (1220)}

A más-más helyre született, eltérő érdekeltségü vagy éppen különböző vallású emberek békés egymás mellett élésének vágya Szent Ferenc számára nem valamiféle elvont eszmeiségből, hanem Isten szeretetéből következett és a Szentírás szövegében gyökerezett. Ebböl a szemszögből az evangéliumi élet szorosan vett követése és a békevágy - áttételesen és a rendalapító szándékától függetlenül - egyben egy olyan éles társadalomkritikát is jelentett, amelyet egy gyorsan növekvő létszámú szerzetesrend szervezeti keretei között már nem lehetett az eredeti formában képviselni. Ezeknek az intézményes korlátoknak a kialakulása értelemszerủen maga után vonta a ferences rend egyházi keretek közé történő mélyebb betagozódását, amely egyben garanciát is jelentett az e hagyományt követők számára, hogy a rendalapító lelkülete és szellemisége tovább élhet immár az egyházi hierarchia keretein belül. Más oldalról azonban, a Ferenc személyes példájával is megerősített, muszlimok közötti missziós tevékenység követendő mintává is vált néhány rendtag számára, és ennek hatása alig egy évvel az egyiptomi út után már jelentkezik.

Ferenc nem várta meg az V. keresztes hadjáratot lezáró, 1221-es fegyvernyugvás megkötését Egyiptomban. A szultánnal való találkozást követő évben már a Szentföldön volt, és itt értesülhetett öt társának a mai Marokkó területén elszenvedett vértanúságáról. A ferences rend első vértanúivá vált Adjutusz, Akkurziusz, Berárd, Péter és Ottó testvérek esete ugyanakkor szintén befolyásolhatta Ferenc elképzeléseit a muszlim térségekben végzett missziós tevékenységre vonatkozóan. A 15. században szentté avatott vértanúk nagyjából akkor érhették el a mai Marokkó területét, amikor Ferenc és alKámil találkozott egymással. A rendalapítóval ellentétben azonban az öt ferences nem az Ajjúbidák alattvalóival, hanem az észak-nyugat-afrikai régió és az Ibériai-félsziget déli része felett regnáló Almohád Birodalom belső rendjére őrködő tisztviselőkkel találkozott. Mivel a testvérek itteni tevékenysége akár egy külön tanulmány témája is lehetne, így az esetre vonatkozó források és a szakirodalom részletes ismerete nélkül ezúttal csak annyit érdemes rögzíteni, hogy a marokkói szultán parancsára előbb kiutasították a ferences testvéreket a muszlim állam területéről, majd amikor ismét visszatértek, betolakodókként kivégezték őket (vö. HOEBERICHTS 1997, p. 74; MOSES 2009, p. 153).

A fenti eset különösen érdekes annak fényében, hogy Szent Ferenc és az egyiptomi uralkodó találkozója teljesen más eredménnyel zárult. A ferences rendtörténet korai szakaszát érintő kutatások leginkább Jan Hoeberichts munkája alapján - úgy tủnik, hogy az 1209-ben III. Ince pápa által szóban jóváhagyott ferences regulát kiegészítő, a muszlim térségekbe induló térítőkről szóló 16. fejezetet egyrészt Szent Ferenc saját tapasztalatai, másrészt a vértanú testvérek történetéből leszürt tanulságok alapján állították össze. ${ }^{21}$ A regula vonatkozó része kétféle viselkedésmódot ajánlott a veszélyes misszióra vállalkozó testvéreknek:

„Az egyik magatartás abban áll, hogy ne pereskedjenek és ne versengjenek, hanem Istenért legyenek alárendeltjei minden emberi teremtménynek, és vallják meg, hogy ők keresztények. A másik magatartásnak pedig az a lényege,

\footnotetext{
${ }^{21}$ Hoeberichts többféle álláspontot bemutatva végül arra a megállapításra jutott, hogy a szóban forgó fejezetet az 1221-es pünkösdi káptalanon fogalmazták meg, majd ezt teljes egészében átvette a regula (vö. HOEBERICHTS 1997, pp. 43-47; pp. 86-87).
} 
hogy ha úgy látják, hogy az Úrnak tetszö dolgot müvelnek vele, hirdessék az Isten igéjét; buzditsák hallgatóikat, hogy higgyék a mindenható Istent, az Atyát és a Fiút és a Szentlelket, mindenek teremtöjét, a megváltó és üdvözitö Fiúistent, és keresztelkedjenek meg és legyenek keresztények, mert ha valaki újra nem születik vízböl és Szentlélekböl, nem léphet be az Isten országába. "22

A fenti idézethez Jan Hoeberichts munkájának megállapításain kívül már kevés újat tehetünk hozzá. A szerző több, mint száz oldalon keresztül elemezte az első ferences regula, önmagában nem túlságosan hosszú 16. fejezetének történeti hátterét és szövegének forrásait (lásd HOEBERICHTS 1997, pp. 7-139). A vonatkozó szövegrész szerint a mindennek és mindenkinek való alávetettség elfogadása és a konfliktusok kerülése a muszlimok közé induló testvérek számára nemcsak ajánlatos, hanem létfontosságú alapelv volt, amelyhez a kisebb testvéreknek, életformájukból adódóan, egyébként is tartaniuk kellett magukat. Ez természetesen ugyanúgy igaz volt a keresztény hit megvallására. Amennyiben viszont a térítők nem ismerték fel az igehirdetés megfelelő módját, idejét és helyét, vagy nem volt lehetőségük végzetük elkerülésére, akkor könnyen lehetett osztályrészük a vértanúság. Röviden: a regula szerint csak akkor buzdítsák hallgatóságukat a megtérésre, „ha úgy látják, hogy az Úrnak tetszö dolgot müvelnek vele” (RNB 16). Emberismeretre, élettapasztalatra, elhivatottságra és mértékletességre volt szükség, amelyek segítségével felismerhetővé váltak a szóbeli evangelizáció megkezdéséhez nélkülözhetetlen körülmények. Más oldalról viszont, az emberi tényezőkön kívül mindenkor szükség volt a körülmények szerencsés alakulására is, mint például Szent Ferenc és alKámil esetében. Ez utóbbi szempont kapcsán érdemes megjegyezni, hogy még ha sikerült is eddig néhány tényezőt felvillantani az 1219-es találkozó körülményeit elemezve, valójában az események megszámlálhatatlanul sok összetevőjét kellene figyelembe venni ahhoz, hogy pontosan lássuk miért is élhette túl Szent Ferenc a szultánnal való találkozót, és miért haltak meg a rend első vértanúi egy évvel később Nyugat-Afrikában. Minden kérdésre az események okainak korabeli vagy jelenkori kutatója sem adhat választ, föleg nem olyan, hitüket különösen mélyen átélö emberek esetében, akik annak tudatában vállalkoztak veszélyes küldetésre, hogy annak sikere nagyobbrészt Istentől függ.

Szent Ferenc legendái közül a Celanói Tamás és a Szent Bonaventura által írtak is kiemelték a rendalapító vértanúság iránti vágyát (lásd CELANÓi 1993, pp. 67-70; BONAVENTURA 2015, pp. 119128). E vágy egy megalkuvás nélküli, a körülményekkel nem számoló térítő tevékenységbe torkollhatott volna, amelynek végeredményeként Ferenc valóban könnyen válhatott volna vértanúvá, de nem így történt. Mint azt Jan Hoeberichts is megállapította, Ferenc arra hívta fel a testvérek figyelmét, hogy bár fel kell készülniük a szenvedésre és az üldöztetésre is, azonban elsősorban ne ezek miatt menjenek a muszlim térségekbe, hanem hogy a béke üzenetét elvigyék a más hitúeknek (vö. HOEBERICHTS 1997, p. 115-116). Hogy mindezt sikerrel tegyék, ahhoz természetesen mindenféle emberi bölcsességen és tapasztalaton, helyzetfelismerésen és emberismereten túl a regula szerint szükség volt még arra is, hogy teljesen az Úrra bízzák sorsukat.

„És emlékezzenek a testvérek arra, bárhol is vannak, hogy átadták magukat, és odaadták magukat az Úr Jézus Krisztusnak. Az ö szerelméért tehát kötelesek kiszolgáltatni magukat a látható és láthatatlan ellenségnek.” (Reg 1995, pp. 3536)

Mint a szintén a regula 16. fejezetéből származó korábbi idézetnél, ebben a szövegrészben is megfigyelhető, hogy a veszélyes feladatra vállalkozó testvéreknek mindenkinek alárendelve és kiszolgáltatva kell tevékenykedniük. Ilyen körülmények között valószínüleg nem is igen lehetett más választása a rendtagoknak, mint a Megváltóra bízni sorsukat, és józan ítélőképességüket megtartva végezni feladatukat. Fentebb már szintén volt róla szó, hogy az előbbire Pelagius bíboros is felhívta a szultán felkeresésére engedélyt kérő Szent Ferenc figyelmét (idézi ToLAN 2007, p. 75). Természetesen

\footnotetext{
${ }^{22}$ Kiemelés a forráskiadvány szerkesztőjétől (RNB 16).
} 
még hosszasan lehetne elemezni az 1209-ben jóváhagyott regula későbbi kiegészítését, azonban az eddigiek alapján is jól látható, hogy a 16. fejezet a rendalapító egyiptomi útjának és a rendtársaival történteknek a tapasztalatai alapján születhetett. Mindezek alapján Ferenc 1220 után is úgy láthatta, hogy a vallások közötti békés eszmecserére még a legzavarosabb idöszakban is van lehetőség, amennyiben a testvérek számot vetnek a körülményekkel, és sorsukat teljesen Istenre bízzák.

\section{A ferences rend betagozódása az egyházi keretek közé}

Szent Ferencnek és követőinek a muszlimokhoz füződő viszonya, illetve általában a békére és a hit erőszakmentes terjesztésére vonatkozó törekvése teljesen ellentétes volt mindazzal, amit a harcoló felek kívántak. Az egyik oldalon, a kereszteseknél elvileg a Szentföld muszlim uralom alóli felszabadítása volt a cél, ezt pedig - más módot nem látván - a fegyverek erejére támaszkodva, erőszakkal kívánták elérni. Az elvi célkitüzés mellett ugyanakkor ott voltak az V. keresztes hadjárathoz kapcsolódó, éppen aktuális hatalmi érdekek is. Így például az itáliai kereskedővárosok financiális szempontjai, vagy a közel-keleti muszlim birodalom akcióképességének hosszú időre történő blokkolásának vágya (ez utóbbi kapcsán csak mellékesen érdemes megjegyezni, hogy egy sikeres hadjárat során megszerzett szentföldi területek megtartása másként nem is lett volna lehetséges hosszabb távon). Más oldalról viszont al-Kámil sem biztos, hogy engedte volna Szent Ferencnek kifejteni nézeteit, ha érdekei mást diktálnak, és uralkodóként valószínüleg maga is tisztában lehetett azzal, hogy még a békére vágyó és egymást tisztelő emberek közössége sem képes adott körülmények között elhozni a szebb világot. Így a rendalapító egyiptomi missziója már csak a hatalmi érdekek miatt sem eredményezhette a hadmozdulatok azonnali félbeszakítását.

Ferenc a fenti tapasztalatok birtokában érkezett vissza Európába: 1220 tavaszán vagy nyarán már Velencében találjuk. Könnyen lehet, hogy már korábban is eljutottak hozzá a hírek, de legkésőbb ekkor már mindenképpen szembesülnie kellett azzal, hogy az Itáliában maradt rendtagok az általa megálmodott életforma, az evangéliumi élet szorosan vett követése helyett inkább rendházakat, képzési intézményeket építettek. Mindez már egy olyan szerzetesi életmód kialakulásának irányába mutató folyamat része volt, amelynek révén a Szent Ferenc által alapított rend egyre inkább a monasztikus közösségekhez kezdett hasonlítani, még ha valójában nem is vált teljesen azzá. Ez egyfajta természetes velejárója volt az egyházi keretek közé történő betagozódásnak (vö. MOSES 2009, p. 156; RotZeTTER, VAN DiJK \& MATURA 1995, p. 40). Szent Ferenc számára - miután visszatért Európába - világossá vált, hogy a rend gyakorlati irányítása meghaladja a saját erőit. Így az alapító előbb Cattani Péternek, majd az 1217-es káptalan által Szentföldre küldött Cortonai Illésnek engedte át a szervezés nehéz munkáját, miközben ő maga továbbra is spirituális vezetője maradt rendjének, sőt bíboros protektort kért a pápától a szerzetesrend számára (vö. ROTZETTER, VAN DIJK \& MATURA 1995, p. 40). A tulajdon nélküli, folyton vándorló életmódot folytató testvéri közösség ideálját, amelyet követve a rendtagok egyrészt karitatív tevékenységet folytatnak, másrészt erős spirituális megalapozottságú missziós munkát végeznek, ezt követően már szorosan az egyházi keretek között kellett képviselni. A rend számára a ferenci lelkület egy olyan követendő szellemiséggé vált, amelyet a testvérek továbbra is megéltek, de ehhez már adottak voltak a keretek is, amelyeken belül egyrészt biztosíthatóvá váltak a szervezett ténykedés feltételei, másrészt pedig a rendtagoknak a későbbiekben már ehhez a szervezeti formához kellett igazítaniuk missziós tevékenységüket. Ahogy az al-Kámillal való találkozás alkalmával, úgy Ferencnek pár évvel később is tudnia kellett, hogy az általa követett eszmei célhoz adott körülmények között milyen út vezethet, és miként maradhat hủ rendje szellemiségéhez.

A rend feletti egyházi felügyelet megerősödése és a szervezeti keretek közé való betagolódás egyben azt is jelentette, hogy ezt követően a ferencesek tevékenysége a közel-keleti és észak-afrikai térségben inkább már az európai hatalmak és a muszlim világ közötti viszonyok, illetve áttételesen, a 
diplomáciai kapcsolatokra nagyobb rálátással bíró pápai udvar döntéseinek függvénye lett. Jan Hoeberichts szerint legalábbis ennek tulajdonítható, hogy a III. Honorius pápa által 1223-ban megerősített regulába már nem kerültek be a muszlim világba készülő térítők viselkedésére vonatkozó részek. Két évvel később Róma már olyan ferences térítőket küldött ismét a mai Marokkó területére, akik számára már kifejezetten a térítő tevékenységet írták elő követendő szabályként. ${ }^{23}$

Az eddigiek alapján azonban annyi mindenképpen kijelenthető, hogy Szent Ferenc és al-Kámil közötti találkozó emléke elevenen élt a rendalapító emlékezetében, és ennek tanulságait igyekezett is örökül hagyni munkáiban, illetve a „meg nem erősített” regula vonatkozó fejezetében.

\section{A Szent Ferenc és al-Kámil szultán közötti találkozó tanulságainak összegzése}

Összegezve a fentebb írtakat leszögezhetö, hogy az V. keresztes hadjárat véres eseményei közepette több körülmény együttállásának eredményeként valósulhatott meg a két karizmatikus személy, Assisi Szent Ferenc és Melek al-Kámil egyiptomi szultán közötti békés eszmecsere, melynek létrejötte önmagában is rendkívüli eseménynek számít.

Ezek közül lényegében két szempontot érdemes kiemelni: az egyik az 1219 szeptemberi hadi helyzet és hatalmi viszonyok, akár a keresztes és a muszlim had viszonylatában, akár az egyes táborokon belül; a másik pedig a találkozó két résztvevőjének személyisége. Az előbbiről szólva mindenképpen fontos figyelembe venni, hogy a fenti időpontban Damietta körül olyan patthelyzet alakult ki a két hadsereg között, amelyben egyik fél sem tudta elérni a másik teljes kapitulációját. Mivel mégis inkább al-Kámil volt szorultabb helyzetben, így ekkor már erősen gondolkodott egy olyan békeajánlaton, amelynek során még Jeruzsálemet is átengedte volna a kereszteseknek. Ha a találkozó két szereplőjét tekintjük, akkor pedig az egyik oldalon ott találjuk az Isten szeretetéből következő béke hirdetése irányába elkötelezett rendalapítót, aki önként kereste ennek leghatékonyabb módját; másrészt pedig a szultán személyiségétől sem állt távol a keresztényekkel folytatott párbeszéd, már ha hatalmi érdekei ezt megengedték. Ez utóbbi szempontra ismét fel kell hívni a figyelmet, hiszen ahogy Ferenc sem mehetett volna át a muszlim táborba egy gyökeresen eltérő hadi helyzet esetén, úgy a szultán sem engedhette volna szabadon távozni vendégét, ha az egyértelmüen térítő tevékenységet folytat harcosai között, vagy ha a muszlim főemberek közötti erőviszonyok úgy alakulnak, hogy ez kedvezőtlenül befolyásolja al-Kámil döntését a jövevény sorsával kapcsolatban. Mindez azonban nem így történt, s ez egyben lehetővé tette azt is, hogy a találkozó mai napig érvényes pozitív tanulságairól lehessen írni.

Források hiányában nem tudjuk pontosan, hogy miről szólhatott a szultán és Szent Ferenc közötti eszmecsere. Nem tudjuk, hogy egy alkalommal találkoztak-e csupán, vagy többször is az alatt a néhány nap alatt, amíg Szent Ferenc és Illuminato testvér a muszlim táborban tartózkodtak. Nem tudjuk, hogy megbeszélésüknek volt-e konkrét, kézzel fogható hatása az akkori hadjárat eseményeire. Azt tudjuk, hogy az akkori muszlim világ egyik igen jelentős uralkodója fogadott két, az ellenséges táborból átsétáló egyszerü, fegyvertelen keresztényt, akiknek semmiféle felhatalmazása nem volt sem az egyház, sem a keresztesek politikai vagy katonai vezetőitől semmiféle tárgyalásra. Valószínüleg az V. keresztes hadjárat vezéreinek jó része nem is hallott még Szent Ferencről és társairól. Szent Ferenc azonban meglepő küldetéstudattól hajtva utazott a Szentföldre és jelent meg a muszlim táborban azzal a szándékkal, hogy nem kisebb személlyel, mint a szultánnal akar beszélni. Úgy tủnik, mintha nem vett volna tudomást sem a körülményekről, erőviszonyokról, a háborús helyzetről, sem arról, hogy semmiféle rangja, tekintélye, hatalma nincs, amely feljogosíthatná egy uralkodóval való tárgyalásra. Úgy tűnik, mintha kilépne a korabeli sztereotípiákból, megkeményedett, jól megokolt

\footnotetext{
${ }^{23}$ A III. Honorius által 1225-ben kiadott Vineae Domini custodes kezdetủ bulla már kifejezetten a nyugat-afrikai muszlim birodalomban folyatott térítö tevékenységet helyezte elötérbe az ottani keresztény közösségek támogatása mellett (vö. HOEBERICHTS 1997, p. 103).
} 
viszonyrendszerekből, és más, sajátos logikát követve kívánna cselekedni. Szándékát bejelentette ugyan Pelagius bíborosnak, mint a pápa legfőbb helyi képviselöjének, de a legátus nem bátorította, sőt arra figyelmeztette, hogy a keresztesek részéről semmilyen segítségre nem számíthat: mintegy lemondott arról, hogy a két testvért élve látja viszont.

A források tanúsága szerint a találkozó mégis létrejött, a szultán fogadta, komolyan vette, megjutalmazta - egyes források szerint anyagi javakkal, mások szerint a Szent Kegyhelyek szabad meglátogatását engedélyező „menlevéllel” - a két szerzetest, akik ezután visszatértek a keresztes táborba. Úgy tünik, hogy Szent Ferenc és al-Kámil szultán a történelem egy pontján, a háborús helyzet ellenére és dacára, egy rövid időre megtalálta a „közös nevezőt”, amely értelemszerủen nem lehetett csupán a hadmüveletekre vonatkozó fegyvernyugvás, vagy béke. Más természetű békét keresett Szent Ferenc, ami már abból is nyilvánvaló, hogy „békemissziójához” eleve semmiféle diplomáciai felhatalmazása nem volt. A történelem arról is tanúskodik, hogy amikor a későbbiekben békeszerződés megkötésére került sor, akkor az továbbra is a hatalmi érdekek által meghatározott módon és időben valósult meg.

A találkozó hosszútávú hatását, illetve eredményét mérlegre téve feltétlenül meg kell említenünk, hogy mindmáig a Ferences Rend tölti be a szentföldi kegyhelyek örzésének feladatát, miután az első ferencesek még a karizmatikus rendalapító életében megérkeztek a Szentföldre. Bár a 800 évvel ezelőtti találkozó és az őrzési szolgálat közötti összefüggést világosan alátámasztó forrás nem áll rendelkezésre, de a rend későbbi szentföldi misszióját és elfogadottságát nehéz lenne Szent Ferenc és al-Kámil szultán ikonizálódott emlékủ egykori találkozójától elvonatkoztatni. A létrejött találkozó és „vallásközi dialógus" hosszútávú szellemi hatását mi sem bizonyítja jobban, minthogy az a történeti emlékezetben - mind a nyugati keresztény gondolkodásban, mind a muszlim hagyományban egyértelmüen pozitív, példa értékủ eseményként rögzült. Olyan erős ez az örökség, hogy például az 1986-ban II. János Pál pápa által kezdeményezett, Assisibe összehívott vallásközi találkozók sorát is mindmáig a kerek 800 évvel ezelőtti rendhagyó történet inspirálja. ${ }^{24}$

\section{Irodalom - References}

BonaVEnTURA, Szent (2015): Szent Ferenc élete. Legenda maior. Középkori Keresztény Írók 7., Szent István Társulat, Budapest. (Berhidai, P.)

BozsóKY, P. G. (1995): Keresztes hadjáratok. Agapé, Szeged.

CelanóI, T. (1993): Celanói Tamás életrajzai Szent Ferencről. Ferences Források 2., Agapé, Újvidék-Szeged-Csíksomlyó. (ford. Balanyi, Gy.; Hidász, F. \& Várnai, J.)

ERNOUL (2009): Chronik von Ernoul (1227-29). In: D. BERG \& L. LEHMANN (Hrsg.): FranziskusQuellen. Die Schriften des heiligen Franziskus, Lebensbeschreibungen, Chroniken und Zeugnisse über ihn und seinen Orden. Im Auftrag der Provinziale Franziskaner, Kapuziner und Minoriten, Butzon \& Bercker, Kevelaer, pp. 1543-1546.

FEDA, A. (1872): Tiré des annales d'Abou 'L-Feda. In: Recueil des historiens des crosides. Historiens orientaux. Tome 1., Académie des Inscriptions et Belles-lettres, Paris, pp. 1-166.

[online] https://archive.org/details/recueildeshistor01acad [letöltés: 2018. június 28]

\footnotetext{
${ }^{24}$ Sajnos a korabeli muszlim történetírók munkáinak elemzésére ezúttal nem kerülhet sor, mivel egy ilyen vállalkozás már szétfeszítené jelen tanulmány kereteit, azonban a keresztes hadjáratokra vonatkozó keleti forrásokat már korábban lefordították a nyugati nyelvekre is. Erre jó példa a Francia Akadémia 19. században indított forráskiadvány-sorozatának, a Recueil des historiens des croisades címü munkának a keretein belül 1872 és 1906 között megjelent öt kötet, amely a keresztes hadjáratokra vonatkozó keleti, muszlim forrásokat dolgozta fel (Historiens orientaux). [online] https://archive.org/details/recueildeshistor01acad [letöltés: 2018. június 28]
} 
FERENC, Assisi Szent: Levél az őrökhöz (Epistola ad custodes). In: HIDÁsz, F. \& VÁRNAI, J. (szerk.) (1995): Assisi Szent Ferenc müvei (Opuscula S. Francisci). Agapé, Novi Sad, pp. 83-84. [LŐR]

FERENC, Assisi Szent: Levél a népek vezetőihez (Epistola ad populorum rectores). In: HIDÁSZ, F. \& VÁRnaI, J. (szerk.) (1995): Assisi Szent Ferenc müvei (Opuscula S. Francisci). Agapé, Novi Sad, p. 85. [LNVEZ]

FERENC, Assisi Szent: A meg nem erösített regula (Regula non bullata). In: HidÁsz, F. \& VÁRNAI, J. (szerk.) (1995): Assisi Szent Ferenc müvei (Opuscula S. Francisci). Agapé, Novi Sad, pp. 23-47. [REG]

HOEBERICHTS, J. (1997): Francis and Islam. Franciscan Press, Quincy.

Huber, T. M. \& L. LeHMANn (2009): Franziskus bei den Chronisten des 5. Kreuzzugs. In: D. BERG \& L. LEHMANN (Hrsg.): Franziskus-Quellen. Die Schriften des heiligen Franziskus, Lebensbeschreibungen, Chroniken und Zeugnisse über ihn und seinen Orden. Im Auftrag der Provinziale Franziskaner, Kapuziner und Minoriten. Butzon \& Bercker, Kevelaer, pp. 1-166.

MolnÁR, P. (2004): Császárság, pápaság és az itáliai nagypolitika. In: KLANICZAY, G. (szerk.): Európa ezer éve. A középkor. II. kötet, Osiris, Budapest, pp. 60-90.

Moses, P. (2009): The Saint and the Sultan. The Crusades, Islam and Francis of Assisi's Mission of Peace. Doubleday Religion, New York.

PETERS, E. (1971): Christian Society and the Crusades 1198-1229. University of Pennsylvania Press, Philadelphia. doi: 10.9783/9780812207361

Runciman, S. (2002): A keresztes hadjáratok története. Osiris, Budapest. (ford. Bánki, V. \& Nagy, M. Zs.)

TACiTUS, P. C. (1998, 2001): Évkönyvek. In: Zsolt, A. (szerk.): Tacitus összes müvei. Szukits, Szeged, pp. 189-398. (ford. Borzsák, I.)

Tolan, J. (2007): Le saint chez le sultan. La rencontre de François d'Assise et l'islam Huit siècles d'interprétation. Seuil, Paris. doi: 10.14375/np.9782020928151

II. VATIKÁNI ZSINAT (2000): Nostra Aetate. Nyilatkozat az egyház és a nem keresztény vallások kapcsolatáról. In: Diós, I. (szerk.): A II. Vatikáni Zsinat dokumentumai. Szent István Társulat, Budapest, pp. 399-407.

VITRY, J. (2009a): Historia Occidentalis, Kap. 32 (vor 8.9.1221). In: D. BERG \& L. LEHMANN (Hrsg.): Franziskus-Quellen. Die Schriften des heiligen Franziskus, Lebensbeschreibungen, Chroniken und Zeugnisse über ihn und seinen Orden. Im Auftrag der Provinziale Franziskaner, Kapuziner und Minoriten. Butzon \& Bercker, Kevelaer, pp. 1538-1543.

ViTRY, J. (2009b): Brief aus Damiette (Febr./März 1220). In: D. BERG \& L. LEHMANN (Hrsg.): Franziskus-Quellen. Die Schriften des heiligen Franziskus, Lebensbeschreibungen, Chroniken und Zeugnisse über ihn und seinen Orden. Im Auftrag der Provinziale Franziskaner, Kapuziner und Minoriten. Butzon \& Bercker, Kevelaer, pp. 1536-1538. 
VII. Melléklet - Appendix

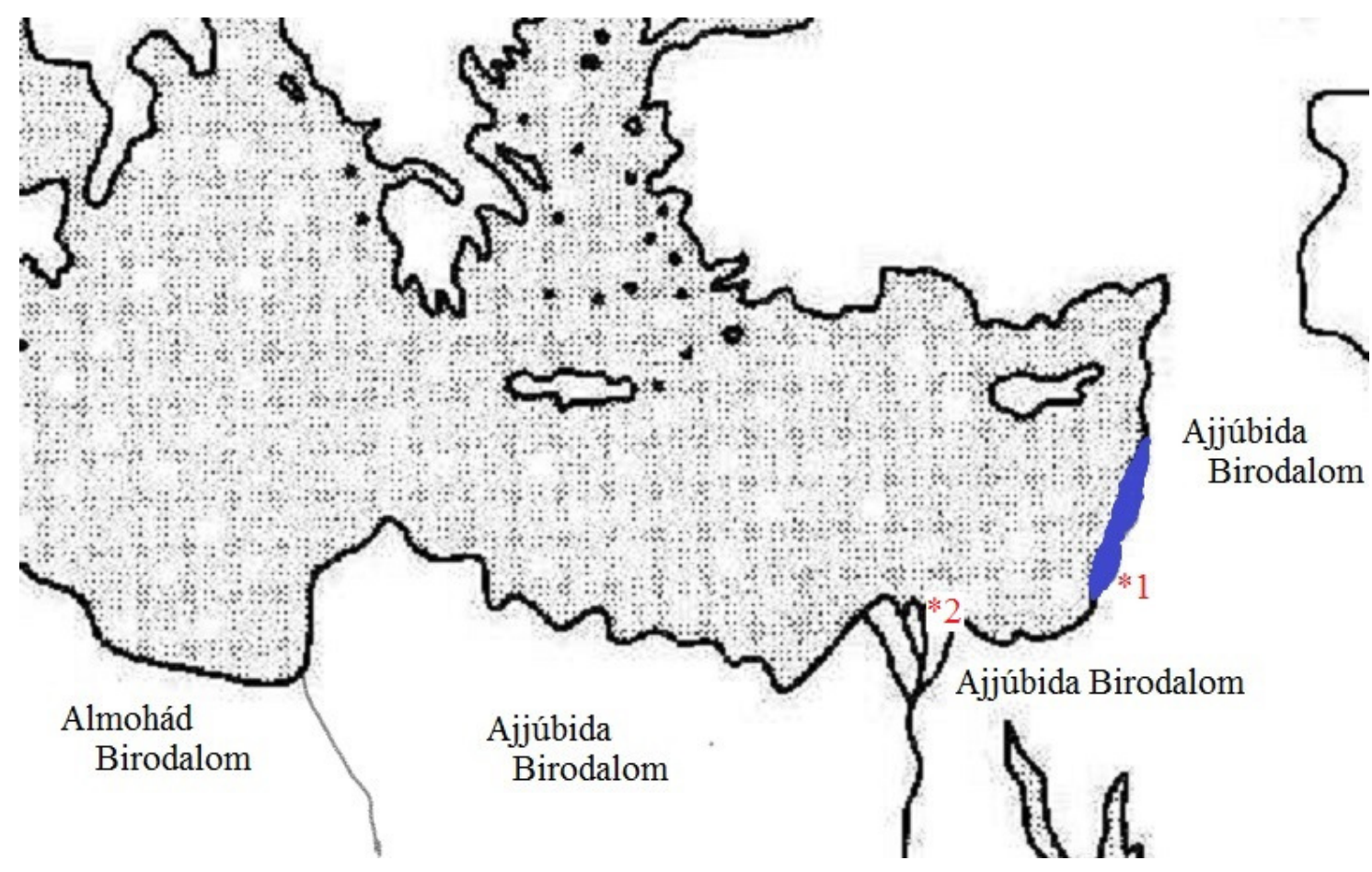

1. térkép. Egyiptom és a Szentföld 1219-ben.

1. Jeruzsálem, 2. Damietta, a kékkel jelölt rész a Jeruzsálemi Királyság ekkori területét jelöli.

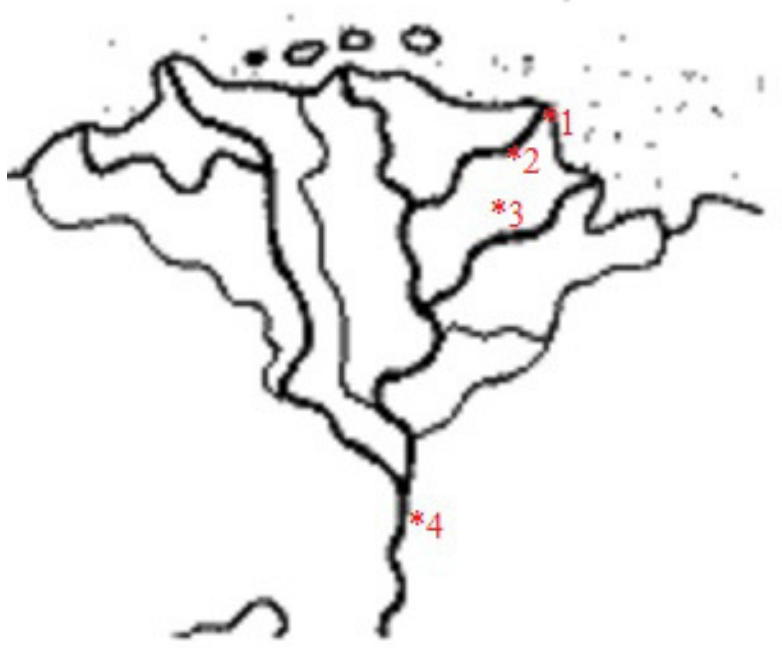

2. térkép. A Damiettáért folyó harc főbb helyszínei.

1. Damietta, 2. Fariskur, 3. Bahr asz-Szagir, 4. Kairó. 


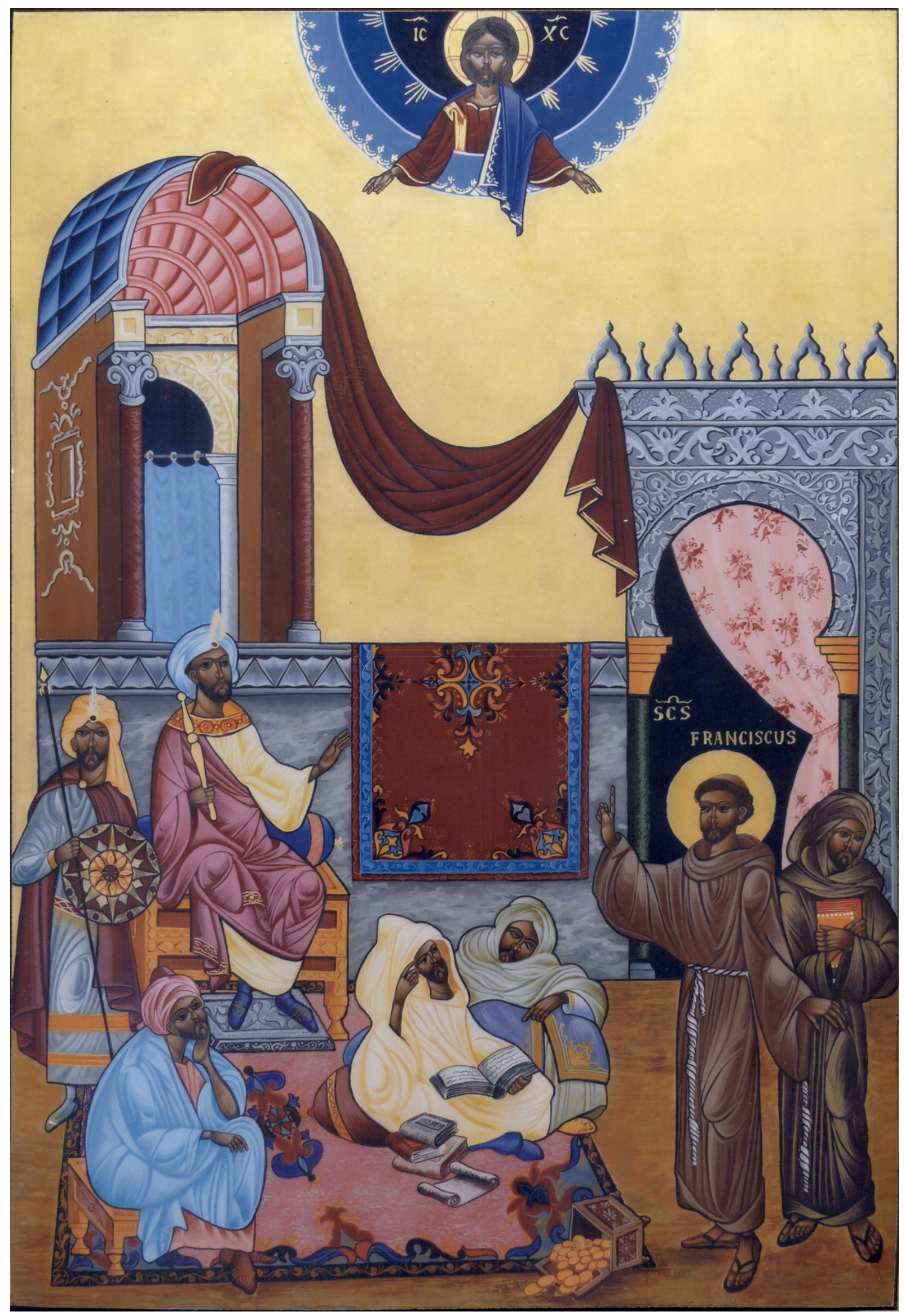


